Natalia Jakubowska

[Wrocław ]

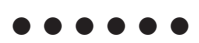

\title{
Między Usznią a Domaniowem. Przesiedleńcy z Kresów Wschodnich osiedleni na Ziemiach Zachodnich
}

Wrocławski Rocznik

Historii Mówionej

Rocznik IV, 2014

ISSN 2084-0578

Najstarsze pokolenie Domaniowa, miejscowości leżącej $30 \mathrm{~km}$ na południowy zachód od Wrocławia, w większości pochodzi ze wsi Usznia, która obecnie znajduje się na terenach Ukrainy, a przed wojną leżała na terenie województwa tarnopolskiego ${ }^{1}$, na wschód od miasta powiatowego Złoczów. Mieszkańcy Uszni na Ziemie Zachodnie przybyli w 1945 r. Bohaterkami artykułu są seniorki: Domicela Rypałowska, Józefa Rudnik, Domicela

$1 \quad$ Podział administracyjny po wybuchu wojny zmieniał się. W wyniku porozumienia radziecko-niemieckiego z 23 sierpnia 1939 r. omawiane tereny dostały się pod okupację radziecką i wprowadzono podział na obwody. Usznia znalazła się w obwodzie lwowskim. Po wkroczeniu wojsk niemieckich na obszar Galicji Wschodniej w $1941 \mathrm{r}$. z terenów byłych woj. tarnopolskiego, stanisławowskiego i części lwowskiego utworzono Dystrykt Galicja, który włączono do Generalnego Gubernatorstwa i wprowadzono podział na tzw. starostwa powiatowe. Wtedy Usznia należała do starostwa Złoczów. Kolejne zmiany administracyjne nastąpiły po powrocie Galicji Wschodniej pod okupację radziecką, kiedy to przywrócono podział na obwody z lat 1939-1941. G. Hryciuk, Przemiany narodowościowe i ludnościowe w Galicji Wschodniej i na Wotyniu w latach 1931-1948, Toruń 2005, s. 33-43. 
Domańska, Adela Dumańska oraz Józefa Kawałko². Podzieliły się z autorką wspomnieniami o tym, jak zapamiętały rodzinną wieś, jak żyło się w czasach okupacji radzieckiej i niemieckiej tych terenów, jak wyglądało przesiedlenie i osiedlenie się na Ziemiach Zachodnich.

Sylwetki seniorek zaprezentowane były na łamach "Gazety Powiatowej - Wiadomości Oławskie” w rubryce „Pierwsi domaniowianie”. Pomysł przedstawienia ich losów zrodził się po publikacji cyklu artykułów o pierwszych oławianach. Ponadto obecnie żyje coraz mniej przedstawicieli najstarszej generacji przesiedleńców z Uszni, dlatego to ostatnia chwila, aby ich relacje zebrać i spisać. Zasadniczym materiałem, na którym się opieram, to opowieść autobiograficzna. Zapis cyfrowy relacji przeprowadziłam za pomocą dyktafonu z respondentkami z najstarszej generacji, która przeżyła przesiedlenie z Uszni do Domaniowa. Rozmowy przeprowadziłam 28, 29 i 30 listopada 2011 r. oraz 7 lutego 2012 r. Odbywały się pojedynczo ze świadkami, w miłej, serdecznej atmosferze, w domu respondentek. Ponadto odbyłam kilka krótkich rozmów telefonicznych, w czasie których dopytywałam o szczegóły. Łącznie nagrania stanowią ok. 8 godzin 14 minut $^{3}$. Rozmówczynie z rozrzewnieniem i tęsknotą wracały pamięcią w rodzinne, kresowe strony. Zadając te same pytania wszystkim respondentkom, dążyłam do uzyskania następujących informacji: dane osobowe: miejsce i data urodzenia, poziom wykształcenia, dane rodziców i ich zawód, informacje o rodzeństwie; droga życiowa respondentki: jak zapamiętano rodzinną wieś, okres szkolny, przeżycia wojenne z okresu okupacji niemieckiej i radzieckiej, data i okoliczności wyjazdu z Kresów, podróż i data przybycia na Ziemie Zachodnie; życie na nowej ziemi: poszukiwanie miejscowości do zamieszkania, pierwsze wrażenia z Domaniowa, współżycie z Niemcami, zagospodarowanie w nowym miejscu zamieszkania, kontynuowanie tradycji i zwyczajów ze Wschodu. W trakcie relacji pozwalałam rozmówczyniom na swobodne budowanie narracji, opowiedzenie tego, co wydawało się im ważne, w wyniku czego pojawiały się ciekawe wątki, o które nie pytałam (np. wywózka na roboty przymusowe, rola ks. Eugeniusza Nowaka), a w razie

2 Sylwetki tych pań, na podstawie ich relacji, zostały zaprezentowane na łamach „Gazety Powiatowej - Wiadomości Oławskie”, rubryka „Pierwsi domaniowianie”, numery 50 (970) z 15 XII 2011 r., 1 (973) z 5 I 2012 r., 3 (975) z 19 I 2012 r., 4 (976) z 26 I 2012 r., 8 (980) z 23 II 2012 r.

3 W dalszej części artykułu nie będę opatrywała przypisami cytatów z poszczególnych wypowiedzi respondentek. 
konieczności zadawałam pytania szczegółowe. W artykule podaję większość relacji, które wiążą się z tematem. Rozmowy nie są transkrybowane, jedynie przepisane ręcznie do brudnopisu, w celu sprawniejszego dostępu do poszczególnych wątków. Relacje rozmówczyń zostały poddane redakcji stylistycznej, ale z zachowaniem indywidualnego stylu wypowiedzi.

Grupę respondentów dobrałam, wykorzystując informacje otrzymane od rodziny mieszkającej w Domaniowie, również przesiedleńców z Kresów Wschodnich. Dlatego też wydaje mi się, że dotarłam do możliwie najważniejszych osób, które mogły opowiedzieć o swojej historii związanej z Usznią, przesiedleniem i Domaniowem. Jedna z osób odmówiła udzielenia wywiadu. Z inną panią, z rocznika 1923, nie udało się przeprowadzić rozmowy ze względu na brak sprawności umysłowej, związanej z wiekiem. Niestety z moich informacji wynika, że nie żyją już mężczyźni z tego pokolenia, którzy dobrze pamiętaliby czasy Uszni i przesiedleń.

Obraz przeszłości utrwalony w pamięci rozmówczyń wydaje się dość podobny, a przede wszystkim trzy poruszane w rozmowach kwestie. We wszystkich relacjach podkreślano, że wieś Usznia zapamiętano jako dużą miejscowość, z wieloma mieszkańcami. Po drugie, w pamięci respondentek zachowało się wspomnienie o bardzo długiej i uciążliwej podróży na zachód. Często zdarza się, że miejsca lub wydarzenia zapamiętane za czasów dzieciństwa czy młodości wydają się mieć większe rozmiary niż w rzeczywistości. Po trzecie, prawie wszystkie rozmówczynie podkreślały ważną rolę księdza Eugeniusza Nowaka w ich społeczności, zarówno w czasie przesiedlenia, jak i osiedlenia w nowym miejscu.

Z relacji można wywnioskować, że rozmówczynie pochodziły ze skromnych, ubogich, rolniczych rodzin o niedużych gospodarstwach ${ }^{4}$. Najstarsza wśród generacji przesiedleńców, Domicela Rypałowska, urodziła się 26 kwietnia 1923 r. w Uszni. Mieszkała tam wraz z rodzicami Marcelim Kłakiem i Rozalią z domu Domańską oraz bratem. Ojciec zajmował się rolą, a matka była krawcową. W 1940 r. wyszła za mąż za Tadeusza Rypałowskiego. O historii rodzinnych ziem opowiadał jej dziadek Kazimierz Domański, który służył w wojsku cesarza Franciszka Józefa I.

$4 \quad$ W zbiorach Archiwum Państwowego we Wrocławiu znajdują się dokumenty - orzeczenia o pozostawionym mieniu na Wschodzie, jednakże nie są udostępniane osobom postronnym. 
Józefa Rudnik urodziła się w Uszni w 1927 r. Jej rodzice Józefa z domu Kłak i Wojciech Gołąb (zmarł, gdy mała Józia miała 9 lat) zajmowali się gospodarstwem, a pani Józefa miała pięcioro rodzeństwa.

Domicela Domańska, córka Wiktora Wodzińskiego i Emilii z domu Bojakowskiej, urodziła się również w Uszni w 1929 r. Była najstarsza z piątki rodzeństwa, a jej rodzice zajmowali się rolą.

Adela Dumańska przyszła na świat w Uszni w 1933 r. jako córka Anny z domu Domańskiej i Józefa Gabryluków, również rolników.

Józefa Kawałko urodziła się w Uszni 13 sierpnia 1927 r., ale wychowywała w Białym Kamieniu. Jej rodzice to Antonina z domu Gabryluk i Kazimierz Kuczmowscy. Miała trójkę rodzeństwa: młodszą siostrę Stefanię, starszego brata Józefa i młodszego Bronisława.

\section{Wspominając Usznię...}

Panie ze wzruszeniem i rozrzewnieniem wspominają rodzinną wieś.

- „Kiedy myślę o Uszni, najpierw przypominam sobie swój piękny, duży dom. Wkoło drzewa, 3 morgi ogrodu, kwiaty, łąka, orane pola" - mówi Józefa Rudnik. - „A zaraz niedaleko płynął Bug , chodziliśmy się kąpać. [...] Przypominają mi się lasy, grzyby, maliny chodziliśmy zbierać". Adela Dumańska dodaje: - „To była piękna wieś, naokoło lasy, okolice piękne, góry, ale była bieda. Były tam liczne źródełka [w tym jedno] na Świętej Górze, źródło Bugu [niedaleko] wypływało". Usznia położona jest $3 \mathrm{~km}$ od miasta Sasów. Są to malownicze tereny z lesistymi dolinami rzek i górzystym krajobrazem, gdyż znajduje się tam pasmo zalesionych wzniesień, zwane Woroniakami ${ }^{6}$. Józefa Kawałko przyznaje, że niezbyt dobrze pamięta rodzinną wieś, ponieważ przez większość dzieciństwa wychowywała się w Białym Kamieniu. Stąd też historia Józefy jest nieco odmienna od życiorysów pozostałych bohaterek artykułu. Jej matka, Antonina Kuczmowska, po porodzie najmłodszego brata Józefy, Bronisława, poważnie zachorowała i została na długo w szpitalu. Ojciec, Kazimierz, był dużo starszy od Antoniny, która była jego drugą żoną. Po dwudziestu latach pracy w Ameryce wrócił spracowany i schorowany. Gdy astma utrudniała mu normalne życie, również trafił do szpitala. Nie miał się

5 Źródło Bugu wybija w oddalonym o $10 \mathrm{~km}$ od Sasowa (wieś sąsiadująca z Usznią) Werchobużu.

$6 \quad$ G. Rąkowski, Przewodnik po Ukrainie Zachodniej. Ziemia lwowska, cz. III, Prószków 2007, s. 288. 
kto opiekować Józefą i jej rodzeństwem. Wraz z młodszą siostrą Stefanią zostały oddane do klasztoru szarytek w Białym Kamieniu. Chłopców tam nie przyjmowano, więc brata Bronisława wychowywała ciotka, Józefa, najstarszego z rodzeństwa, przygarnął poznany w szpitalu lekarz. Józia w klasztorze spędziła 8 lat. W Białym Kamieniu ukończyła 5 klas szkoły powszechnej. Gdy miała 11 lat, jej matka była na tyle zdrowa, że Józefa mogła wrócić do rodzinnego domu w Uszni. Nie było już w nim ojca, który umarł 5 lat wcześniej. - „Pamiętam, że u nas na Uszni to jakieś ludzie byli dziwni, bo nie mówili po polsku, tylko po ukraińsku. Ja przyszłam z Białego Kamienia, my [z siostrą] umiałyśmy ładnie po polsku, bo nas tam [w Białym Kamieniu] uczono wspomina. - Ja właściwie nie bardzo znam Usznię. [...]. - Myśmy mieszkali na środkowej ulicy, taka rzeczka płynęła, my mieszkaliśmy za nią. [...] Był młynek7 , kilka domów i nasz. Mieliśmy duży ogród".

Jak podaje G. Rąkowski, Usznia w XV w. była królewszczyzną, a w kolejnym wieku należała do rodziny Sieneńskich. Pod koniec XIX wieku Józef Schneider, właściciel znajdującego się tam majątku, zapisał go zgromadzeniu szarytek ${ }^{8}$. Domicela Rypałowska wspomniała o swoim dziadku, który służył w wojsku cesarza Franciszka Józefa I: - „Mnie najwięcej dziadzio opowiadał. Pamiętał swoją prababkę [...]”. Jako małej dziewczynce przekazywał historię ziem, na których powstała Usznia, jeszcze z okresu zaboru austriackiego i powstania styczniowego. „My należeli za Austrii pod Biały Kamień, to była mała mieścina. Tam z Wiednia była hrabina i tam wybudowała klasztor, kościół. Był tam ogromny majątek i w nim były siostry szarytki. [...] Ta hrabina była bardzo dobra, nie miała dzieci, to zrobiła takie przedszkole i dzieci wiejskie, biedne chowała. Jak umierała, zapisała majątek na sieroty i siostry zakonne" ${ }^{\prime}$. Usznia była wsią sołecką

Tak nazywano mniejszy młyn, który funkcjonował na wsi.

G. Rąkowski, op. cit., s. 293.

Nie znalazłam jednak w literaturze potwierdzenia informacji o hrabinie. Według ks. A. Schletza, za rządów siostry Karoliny Juhel (1881-1905) szarytki wybudowały w Białym Kamieniu szkołę gospodarczą wraz z internatem dla małorolnych gospodyń. Zob. A. Schletz, Zarys historyczny Zgromadzenia Sióstr Miłosierdzia w Polsce, „Nasza Przeszłość. Studia z dziejów Kościoła i kultury katolickiej w Polsce”, t. XII, Kraków 1960, s. 133-134. Informacje o szarytkach w Białym Kamieniu znajdują się także w schematyzmach archidiecezji lwowskiej zob. Schematyzm Kościoła Rzymsko-katolickiego w Rzeczypospolitej Polskiej, oprac. Z.A. Czernicki, Kraków 1925, s. 171; Schematismus Archidioecesis Leopoliensis Ritus Latini, Leopoli 1939, S. 156. 
w gminie Biały Kamień, w powiecie złoczowskim oraz siedzibą parafii ${ }^{10}$. Według Schematyzmu Archidiecezji Lwowskiej z 1931 r., Usznia należała do parafii w Białym Kamieniu, w dekanacie złoczowskim ${ }^{11}$, ale w Schematyzmie z 1936, 1938 i 1939 r. Usznia była już samodzielną parafią z liczbą odpowiednio 1390, 1400 i 1435 wiernych rzymskokatolickich ${ }^{12}$. W latach 1900-1901 wybudowano we wsi neobarokowy kościół pw. św. Józefa. Obecnie jest opuszczony. Józefa Kawałko wspominała, że ponieważ w domu się nie przelewało, pracowała na uszeńskiej plebanii: „Pomagałam tamtejszej gospodyni - mówi Józefa - to była wykwalifikowana kucharka, szykowała potrawy, których nigdy wcześniej nie widziałam. Ja sprzątałam, myłam podłogę i codziennie rano gotowałam księdzu mleko na śniadanie”. Oprócz kościoła rzymskokatolickiego znajdowała się tam również drewniana cerkiew $^{13}$. We wsi funkcjonowała szkoła powszechna, dwa młyny i sklepy. „Na Uszni był kościół, cerkiew, dwa młyny. Jeden duży, napędzany wodą, robił mąkę, i jeden mały młynek, co robił kaszę jaglaną, gryczaną, też napędzany wodą - wspomina Józefa Rudnik - było takie źródło, Krynica mówili. [...] Było kółko rolnicze, sklep, mleczarnia oraz ochronka"14. D. Domańska również pamięta, że w młynach wyrabiano kaszę gryczaną i jaglaną (pszono). Wspominała, że na wsi istniała ukraińska czytelnia. Domicela Rypałowska pamięta, że na wsi była także świetlica. Mieszkańcy zajmowali się głównie rolnictwem. Według Księgi adresowej Polski z 1929 r., w Uszni były: jedna akuszerka, czterech cieśli, trzech kołodziei, trzech kowali, jeden krawiec, dwóch dzierżawców młynów, dwóch rzeźników, jeden stolarz, jeden szewc, sklep bławatny (oferujący tkaniny), kooperatywa „Jedność”, piwiarnia,

10 H. Komański, Sz. Siekierka, Ludobójstwo dokonane przez nacjonalistów ukraińskich na Polakach $w$ województwie tarnopolskim 1939-1946, Wrocław 2006, s. 512.

11 Schematismus Archidioecesis Leopoliensis Ritus Latini, Leopoli 1931, s. 169.

12 Schematismus Archidioecesis Leopoliensis Ritus Latini, Leopoli 1936, s. 195; Schematismus Archidioecesis Leopoliensis Ritus Latini, Leopoli 1938, s. 110; Schematismus Archidioecesis Leopoliensis Ritus Latini, Leopoli 1939, s. 110. Schematyzm z 1936 podaje również liczbę grekokatolików - 550 i Żydów - 54, innych - 1. Brak takich danych w Schematyzmie z 1938 i 1939 r.

13 Parafia grekokatolicka znajdowała się w Sasowie. W 1936 r. liczbę wyznawców greckokatolickich w Uszni oszacowano na 550. Zob. Stownik geograficzny Królestwa Polskiego i innych krajów słowiańskich, Warszawa 1892, s. 855; Schematismus..., 1936, s. 195.

14 Forma przedszkola. 
wyroby tytoniowe ${ }^{15}$. Natomiast w Stowniku geograficznym Królestwa Polskiego podano - niewspomnianą w Księdze adresowej - kasę pożyczkową gminną oraz szkołę etatową 1-klasową ${ }^{16}$.

W styczniu 1942 r. powstał chór kościelny. Ten czterogłosowy zespół tworzyli chłopcy i dziewczęta. Za jego założyciela uznaje się Antoniego Bojakowskiego, również mieszkańca Uszni. Co ciekawe, chór istnieje do dziśs ${ }^{17}$. Jeszcze w Uszni w chórze śpiewała Józefa Kawałko: - „Wieczorami schodziliśmy się na próby - mówi - to była moja jedyna rozrywka”. Domicela Domańska wspominała, że również jej rodzice śpiewali w tym chórze, a ona sama należała do młodzieżowej grupy śpiewającej w kościele. Domicela pamięta również, że mieszkańcy wsi organizowali jasełka i przedstawienia.

Moje rozmówczynie wspominały, że w odległości około $2 \mathrm{~km}$ od Uszni istniała przed wojną fabryka papieru, w której pracownicy dobrze zarabiali. „Wybudowano ją jeszcze w czasach zaborów, ojciec tam rękę stracił w maszynie do papieru [...] dziadek mi to opowiadał" - wspomina Domicela Rypałowska.

W wielonarodowej wspólnocie

Kresy Wschodnie stanowiły obszar zróżnicowany pod względem języka, wyznania i kultury. Wyraźnie wyodrębniała się ludność żydowska, która miała własny język, gminę, synagogi, szkoły, instytucje kulturalne, normy postępowania i obyczajowośćc ${ }^{18}$. W okresie II wojny światowej nastąpiła intensyfikacja napięć $\mathrm{w}$ relacjach międzyetnicznych, zdeterminowana przez: agresję niemiecką i radziecką, politykę okupantów, działania ugrupowań politycznych i wojskowych oraz przesunięcia granic po II wojnie i transfery ludności ${ }^{19}$.

15 Księga adresowa Polski (wraz z W. M. Gdańskiem) dla handlu, przemystu i rolnictwa, Warszawa 1929, s. 1714.

16 Stownik geograficzny..., s. 855.

17 Dzięki temu, że większość jego członków po wojnie osiedliła się głównie w Domaniowie, pozwoliło to kontynuować wspólne śpiewanie. Potem chór zasiliły ich dzieci oraz mieszkańcy Domaniowa niepochodzący z Uszni. W latach 7o. zespół przestał funkcjonować. Dopiero w 1987, po obchodach 45-lecia istnienia, pojawił się ponownie pomysł reaktywacji chóru. Wtedy wymyślono nazwę „Jubilat”. W 2012 r. chór obchodził uroczyście jubileusz 70-lecia pracy artystycznej.

18 S. Ciesielski, Kresy Wschodnie - dynamika przemian narodowościowych, [w]: Kresy Wschodnie II Rzeczypospolitej. Przeksztatcenia struktury narodowościowej 19311948, red. S. Ciesielski, Wrocław 2006, s. 8.

19 Ibidem. 
„W tamtych czasach na Uszni było 75\% Polaków, a 20\% Ukraińców mówi J. Rudnik - my byliśmy tam razem, chodziliśmy do szkoły, tylko oni mieli swoją lekcję religii, a my swoją. Oni byli grekokatolicy, mieli święta 14 dni później. My się bardzo kochaliśmy, chodziliśmy razem, były koleżeństwo, w szkole nie było żadnej różnicy”. Domicela Domańska zapamiętała Usznię jako dużą miejscowość, na którą składało się ponad 500 numerów domów Polaków i 100 numerów gospodarstw Ukraińców. Według spisu z 1921 r., we wsi były 362 zagrody i 1988 mieszkańców. 1372 stanowiły osoby wyznania rzymskokatolickiego, 496 greckokatolickiego, a 120 mojżeszowego. Narodowość polską podało 1440 osób, rosyjską 428, a żydowską $120^{20}$. W 1931 r. istniały 354 zagrody, a liczba mieszkańców zmniejszyła się do 1802 osób ${ }^{21}$. Brakuje takich szczegółowych danych z lat wojennych. W źródłach można odnaleźć dane ilościowe w obrębie województwa, powiatu lub starostwa ${ }^{22}$.

Wszystkie panie wspominały, że przed wojną Polakom i Ukraińcom dobrze mieszkało się razem w Uszni: - „Ludzie się jednoczyli, my szliśmy na święta ukraińskie, a Ukraińcy na polskie, razem świętowaliśmy - wspomina Adela Dumańska - a potem była nienawiść. Bo Ukraińcy chcieli samodzielnej Ukrainy. Najpierw się razem bawili, a potem mordowali. Ukraińcy byli dobrymi sąsiadami, dopóki ta nienawiść nie nadeszła”.

\section{W czasach okupacji}

II wojna światowa wydaje się najczarniejszym okresem w życiu ówczesnych mieszkańców Uszni. W wyniku paktu Ribbentrop-Mołotow, Kresy Wschodnie znalazły się pod okupacją radziecką. Józefa Kawałko pamięta wybuch wojny, bo bardzo się bała radzieckich żołnierzy: - „Kiedy przyszli Ruscy, na Uszni śmierdziało dziegciem - mówi. - Boże, co to była za hołota, na sznurkach karabiny, parciane buty. Napadali na młode dziewczyny, byli jak bydło. Baliśmy się ich strasznie”. Natomiast Domicela Domańska wspomniała o zamordowaniu brata jej matki, zakonnika Andrzeja

20 Skorowidz miejscowości Rzeczypospolitej Polskiej (opracowany na podstawie wyników pierwszego powszechnego spisu ludności z dn. 3 o września 1921 r. i innych źródeł urzędowych), t. XV, województwo tarnopolskie, Warszawa 1923, s. 28.

21 H. Komański, Sz. Siekierka, op. cit., s. 512.

22 Zob. G. Hryciuk, op. cit. 
Bojakowskiego $^{23}$, dwóch jej kuzynów oraz dziadka. Stało się to 2 lipca $1941 \mathrm{r}$. za sprawą NKWD w Czortkowie, w okresie masowych mordów dokonywanych przez wycofujące się już wtedy NKWD ${ }^{24}$.

Radzieccy okupanci dążyli do sowietyzacji i unifikacji zagarniętych obszarów z resztą państwa ${ }^{25}$. W tym celu m.in. zmienili podział administracyjny kresowych ziem. Wprowadzili również zmiany w szkolnictwie, m.in. zlikwidowano naukę religii, języka łacińskiego, a także historii i geografii Polski. Nauka była obowiązkowa i bezpłatna. Wybór języka wykładowego należał do władz wydziałów oświaty, które miały uwzględniać skład narodowościowy uczniów i deklaracje rodziców. W rezultacie szkoły niższego szczebla zostały zukrainizowane ${ }^{26}$.

Informacje na ten temat pojawiły się w relacjach bohaterek artykułu. Według nich, w Uszni była szkoła 7-klasowa ${ }^{27}$. Józefa Rudnik wspomina: „Na Uszni ukończyłam przed wojną 5 klas. Ksiądz Goldewicz na wsi prowadził wieczorową szkołę i ja tam chodziła do 6 klasy. Potem przyszli Ruskie i cofnęli znowu do piątej klasy. [...] To było w starej szkole. Jak już wyjeżdżaliśmy na zachód, postawiona była już nowa szkoła, tylko jeszcze okien brakowało, ale Ukraińcy już się w niej uczyli”. Potwierdziła to także Domicela Rypałowska, mówiąc: „Była u nas szkoła drewniana, ja się jeszcze w niej uczyłam, dopiero przed samą wojną, w 1937 r., zaczęli budować nową szkołę, tak, że jak my wyjeżdżaliśmy, to nie była jeszcze skończona, nie było okien, ale był dach. Szkoła była murowana, dwupiętrowa”. Domicela Rypałowska i Domicela Domańska ukończyły w Uszni 7 klas, Adela Dumańska zaś 3 klasy. Rypałowska kontynuowała naukę w I klasie gimnazjum, ale przerwał ją wybuch wojny: - „Miałam granatowy mundurek, białą rogatywkę i plecak oraz warkocze. A byliśmy w internacie u sióstr zakonnych. Do gimnazjum nie przyjmowali z krótkimi włosami, musiały być warkocze, nawet krótkie, ale na kokardę. Jeden warkocz mam do tej pory, na pamiątkę zostawiłam".

23 Dziś toczy się proces beatyfikacyjny brata Andrzeja Bojakowskiego. Nieco więcej o tym mordzie w: R. Dzwonkowski, Leksykon duchowieństwa polskiego represjonowanego w ZSRS 1939-1988, Lublin 2003, s. 18.

24 G. Hryciuk, op. cit., s. 185-186.

25 S. Ciesielski, op. cit., s. 9.

26 E. Czop, Obwód lwowski pod okupacją ZSRR w latach 1939-1941, Rzeszów 2004, s. $169-170$.

27 Relacja J. Rudnik, D. Domańskiej oraz D. Rypałowskiej. Pozostałe osoby nie wspominają o szkole 7-klasowej. 
Na wsi zawiązało się również harcerstwo. „Założyli je przed wojną nauczyciele - wspomina Domicela Rypałowska - ja byłam zastępową". Harcerką była także Józefa Rudnik, kiedy uczęszczała do klas 3-5.

\section{Tragiczne wspomnienia}

Zdecydowanie gorszy był czas od 1941 do 1945 r., czyli okres okupacji niemieckiej (1941-1944) i powtórnej radzieckiej (1944-1945). Ze względu na tragiczne wydarzenia związane z eksterminacją ludności żydowskiej i mordami dokonywanymi przez Ukraińców na Polakach lata 1941-1945 wspominane są jako te, które głęboko wryły się w pamięć mieszkanek Uszni. „Pamiętam, że raz Niemcy, a raz Ruskie przychodzili - opowiada Domicela Domańska - pamiętam, jak prowadziłam siostry pod Homiec ${ }^{28}$, a bomby tak strasznie haratały. Schowaliśmy się u wujenki do bunkra, a te bomby ciągle haratały i haratały. Ludzie nie wiedzieli, gdzie uciekać. To było straszne!" ${ }^{29}$. Wydarzenia związane z wkroczeniem i wycofywaniem wojsk niemieckich pamiętają również Józefa Kawałko, Józefa Rudnik oraz Adela Dumańska. „Jak przyszli [Niemcy] to wszystko pachniało, w takich apaszkach, fajne, czyściutkie, aż się chciało patrzeć na nich" - opowiada Józefa Kawałko. „A oni tacy butni szli. [...] Patrzyliśmy jak oni wyglądali, ale to naprawdę było czyściutkie wojsko, aż miło było patrzeć, choć to byli Niemcy-wróg" - śmieje się Józefa.

Adela Dumańska zapamiętała takie zdarzenie: „Jednego razu wojsko niemieckie przyjechało. Ukraińcy wszyscy wyjechali już wcześniej. Wszyscy się baliśmy, oni przychodzili do każdego domu i mówili, że tu będzie wojsko mieszkało. Wtedy czuliśmy się bezpieczniej, bo Ukraińcy wtedy nie mordowali. To był wieczór, ludzie gotowali się na śmierć, ale okazało się, że to było dobre wojsko, frontowe. Dostawaliśmy od nich czekolady, cukierki. Mówili: póki my tu jesteśmy, śpijcie spokojnie, nikt was tu nie ruszy. Niemcy przyszli w 1944 r., ksiądz ich załatwił”. O miejscowym kapłanie i Niemcach opowiadała także Józefa Rudnik: - „Drugi był u nas

28 Wzgórze na północny wschód od wsi, 362 m n.p.m. Źródło: Słownik geograficzny Królestwa Polskiego..., s. 855.

29 Prawdopodobnie miało to miejsce w czasie bombardowania w $1944 \mathrm{r}$. W kwietniu i pierwszych dniach maja odbyły się radzieckie ataki lotnicze, m.in. na pobliski Złoczów. Niewykluczone, że nalot objął także wieś Usznia. G. Hryciuk, op. cit., S. 243 . 
ks. Obtołowicz Józef ${ }^{30}$. Jak już Niemcy uciekali, to przyjechała taka kompania z generałem. On przyszedł na probostwo i zobaczył, że jego kolega w ławce siedzi i ks. Obtołowicz zabrał się z Niemcami, bo tu Ruskie mieli przyjść, jeszcze groźniejsi”.

Uszni nie ominęły i tragiczne losy. „Pewnego razu - opowiada Adela Dumańska - zabrali od nas, nie pamiętam, czy byka czy jałówkę, wyprowadzili na plac, a koło nas były takie dęby [...] i tato mój wyprowadził tę jałówkę. Niemcowi dał, a to była młoda i ona się wyrwała i uciekła. A ten z pistoletem wraca, gdzie chłopy siedzą, a mu nie pomagają. Oni pouciekali, przez podwórze, i w takich okopach ze zboża przy stodole naszej, poukrywali się. Niemiec wleciał do naszego mieszkania. Józio Wojciechowski wskoczył na piec, a jego mama pod łóżko wlazła, a ja biedna stałam na środku. Ten tak popatrzył się, że ja jestem i poszedł. Ja słowa nie mogłam powiedzieć, aż rodzice poszli ze mną do lekarza, tak wielki szok przeżyłam".

W okresie 1942-1944 policja niemiecka przeprowadzała przeciw Polakom akcje represyjne, których pretekstem było zwalczanie partyzantki radzieckiej lub zemsta za ukrywanie Żydów. Warto dodać, że w tym czasie niektórzy uszniacy należeli do podziemnej organizacji niepodległościowej Biały Orzeł, związanej z Armią Krajową. Według H. Komańskiego i Sz. Siekierki, w latach 1943-1945 „we wsi ukształtowała się, pod kierunkiem AK, silna samoobrona, która odpierała skutecznie banderowskie napady na wieś" ${ }^{31}$. W 1943 r. w powiecie złoczowskim utworzono 8. i 9. Kompanię AK. W skład tej drugiej, pod dowództwem st. sierż. sł. st. piech. Stanisława Czederaka „Szakala” (posiadał pseudonim „Rum” w 52. Pułku piechoty AK w Złoczowie), wchodziły osoby z terenów w pobliżu Sasowa, także z Uszni, Gawareczyzny, Huciska Oleskiego, Podhorców, Oleska. Ponadto w Uszni mieściło się dowództwo 9. kompanii ${ }^{22}$. Prawdopodobnie w jej skład wchodziło 120 osób w 2/3 uzbrojonych ${ }^{33}$.

16 maja 1944 r., we współpracy z policją ukraińską, gestapo aresztowało dwudziestu żołnierzy AK, dwunastu mieszkańców Uszni i ośmiu

30 Administratorem i proboszczem parafii w Uszni był Wilhelm Włodarczyk, drugim księdzem Gustaw Obtułowicz, oboje ze Zgromadzenia Księży Misjonarzy Wincentego à Paulo. Schematismus Archidioecesis Leopoliensis Ritus Latini, Leopoli 1939, S. 110,150 .

31 H. Komański, Sz. Siekierka, op. cit., s. 512.

32 J. Węgierski, op. cit., s. 174.

33 Ibidem. 
140 uciekinierów z Grabowej, którzy ukryli się w Uszni ${ }^{34}$. Wśród aresztowanych znaleźli się Rozalia Czederak „Róża” oraz Józef Bojakowski, który został pod koniec 1943 r. dowódcą 9. kompanii po st. sierż. Czederaku. W tym samym dniu, 16 maja, mężczyzn rozstrzelano w pobliskim Kołtowie. Jedyną ocalałą osobą była Czederakowa. W noc poprzedzającą egzekucję została dotkliwie pobita i pozostawiona nieprzytomna w pokoju przesłuchań, a po odzyskaniu przytomności zbiegła do Złoczowa, gdzie się nią zaopiekowano $^{35}$. Wśród jedenastu ofiar, znanych z imienia i nazwiska ${ }^{36}$, znajduje się wuj (brat matki) Adeli Dumańskiej, Łukasz Domański, należący do uszeńskiego Kedywu. Nazwiska ofiar zostały upamiętnione na kamiennej płycie wywieszonej w kościele w Domaniowie. Według informacji podanych w pracy J. Węgierskiego, egzekucja była odwetem gestapowskiego sztabu z Kołtowa za wcześniejszą, choć nieplanowaną, akcję żołnierzy Kedywu z Uszni. Na szosie między Podhorcami a Sasowem, nieopodal wsi Grabowa, natknęli się oni na niedużą kolumnę niemiecką, którą zniszczyli, w wyniku czego zginęło kilkunastu Niemców ${ }^{37}$.

Zagłada Żydów trwała na tych terenach nieprzerwanie od lipca $1941 \mathrm{r}$. i objęła również żydowskich mieszkańców Uszni ${ }^{38}$. O ich prześladowaniu wspominała Józefa Kawałko: „Jak Żydów zabijali, jakie to było straszne! - mówi. - Niemcy zrobili getto, tam, gdzie kiedyś fabryka papieru była. Naprzód [Żydzi] musieli sobie wykopać duże rowy, a później - to u nas było słychać, bo to było może ze $2 \mathrm{~km}$ - jak te maszynowe karabiny terkotały, to słychać było. Boże kochany, jakie to było straszne! Oni stawiali ich na kraju tych rowów i z karabinów maszynowych strzelali. Jedni byli naprawdę zabici, a niektórzy ranni. Za kilka dni, jak tam się dzieci ciekawe schodziły patrzeć, to ta ziemia jeszcze skakała. To było straszne, myśmy uciekali. Już później był spokój. Dolarów było tak nadartych!

34 H. Komański, Sz. Siekierka, op. cit., s. 512; J. Węgierski, op. cit., s. 184.

35 J. Węgierski, op. cit., s. 184. H. Komański, Sz. Siekierka podają inną wersję, według której Rozalia Czederak, żona dowódcy Kedywu AK w Uszni, ocalała dzięki temu, że wyskoczyła z samochodu podczas nocnego transportu. Zob. H. Komański, Sz. Siekierka, op. cit., s. 512.

36 Nie jest znana tożsamość pozostałych ośmiu ofiar. H. Komański, Sz. Siekierka, op. cit., s. 512 .

37 J. Węgierski, op. cit., s. 183-184.

38 G. Hryciuk, Przemiany ludnościowe w Galicji Wschodniej $i$ na Wołyniu w latach 1939-1948, [w:] Kresy Wschodnie II Rzeczypospolitej..., s. 58. 
Żydzi podarli swoje dolary, jakie mieli. U nas na wsi było kilku, nie było z nimi problemu. Handlowali, sklepiki mieli, nikomu nie wadzili". W pamięci Józefy wciąż są obrazy grozy rzeczywistości, które ukazują politykę okupanta niemieckiego: „Chodzili policjanci po domach i wypędzali ludzi na szarwark ${ }^{39}$, darmową robotę. Ja też chodziłam.[...] Myśmy śnieg 3 metry wysoki odgarniali [...]. Miałam może 14-15 lat". W 1942 zmarła matka Józefy. Nastolatka została sama z młodszym bratem. W ramach szarwarku oczyszczała rowy. Natomiast starszego brata Niemcy zabrali do „Baudienstu”. Wykonywał roboty na kolei.

\section{W przymusowej pracy}

We wrześniu 1941 r. Niemcy zapoczątkowali akcje wywózek na roboty w głąb III Rzeszy. Początkowo wyjazdy były dobrowolne, jednak później rekrutacja stała się przymusowa, a przyszłych robotników pozyskiwano metodą łapanki ${ }^{40}$. G. Hryciuk podaje, że w latach 1941-1944 mogło zostać wywiezionych co najmniej 95 tys. Polaków z terenów Galicji Wschodniej ${ }^{41}$. Natomiast W. Bonusiak liczebność robotników przymusowych z dystryktu galicyjskiego oszacował na 325 tys. osób ${ }^{42}$. Na początku czerwca $1942^{43}$ r. Domicela Rypałowska ${ }^{44}$ wraz z mężem zostali zabrani na roboty przymusowe do Prus Wschodnich. W miarę upływu wojny coraz więcej Polaków deportowano właśnie na te tereny. Do Prus Wschodnich i na Dolny Śląsk zesłano ponad 100 tys. osób ${ }^{45}$. „Przyjechało wojsko, otoczyło

39 Był to obowiązek świadczenia różnych prac na cele publiczne, np. budowa dróg, mostów, utrzymanie wałów przeciwpowodziowych itp.

40 G. Hryciuk, Przemiany ludnościowe w Galicji.., s. 58; W. Bonusiak, Rekrutacja, rozmieszczenie i struktura polskich robotników przymusowych do pracy w Rzeszy, [w:] Polscy robotnicy przymusowi w Trzeciej Rzeszy, red. W. Bonusiak, Rzeszów 2005, s. 63.

41 G. Hryciuk, Przemiany ludnościowe w Galicji.., s. 58.

42 W. Bonusiak, op. cit., s. 68.

43 W 1942 r. deportacja z Generalnego Gubernatorstwa osiągnęła największe rozmiary, co spowodowane było stratami w wojnie niemiecko-radzieckiej i potrzebą zastąpienia polskimi robotnikami osób, powoływanych do Wehrmachtu. W. Bonusiak, op. cit., s. 67.

44 Domicela Rypałowska, jako jedyna z bohaterek artykułu, została wywieziona na roboty przymusowe. Jej opowieść oddaje realia rekrutacji i warunków pracy robotników, w wielu wątkach jest zgodna z opisem, jaki można znaleźć w literaturze. Obszerniej na temat pracy przymusowej polskich robotników w Polscy robotnicy...

45 Ibidem, s. 87. 
142 wioskę i złapali młodych - wspomina Domicela - wywieźli nas do majątku w Kuggen koło Królewca. [...] Jechaliśmy w wagonach towarowych. Kazali nam wziąć na dobę jedzenia, a jechaliśmy trzy. A wtedy był duży głód. Moja mama urżnęła 3 snopy żyta, zmieliła i upiekła podpłomyki - placki na wodzie na drogę oraz sera białego z cebulą. W Grajewie dali nam pół bochenka na osobę i trochę miodu. Z tym pojechaliśmy do Królewca. [...] W Niemczech ${ }^{46}$ kazali nam się wszystkim porozbierać, wpędzili do szopy, były prysznice i tam nas kąpali, wszystko od nas zabrali. Myślałam, że pójdziemy do jakiejś komory gazowej, ale każdy dostał woreczek i numer, żeby po nim odebrał woreczek ze swoimi rzeczami. Był tam taki gruby Niemiec i zaglądał w zęby, czy nadaje się do roboty. Ja swoje włosy rozpuściłam. [...] Była tam jakaś trucizna i szczotka. On maczał tę szczotkę i po całej głowie, szyi, wszędzie lali, żeby wydezynfekować. Wymyłam po tym głowę, bo to śmierdziało strasznie, wysuszyłam na słońcu, ale co szarpnęłam, to włosy zaczęły wychodzić”. To z nich Domicela uplotła warkocz, który przechowywała na pamiątkę. Jak wspomina Rypałowska, roboty w niemieckim majątku polegały na pracy w polu oraz w gospodarstwie. Jego właściciele zapewniali wyżywienie i miejsce, w którym Rypałowscy przebywali wraz z pozostałymi robotnikami. Oprócz Polaków były osoby innej narodowości. Robotnicy skierowani do pracy w rolnictwie mieli najcięższe warunki mieszkaniowe. Rzadko kiedy właściciel przyjmował ich do swojego domu, w związku z czym pracownicy przymusowi najczęściej mieszkali w pomieszczeniach gospodarczych ${ }^{47}$. Częstym problemem związanym z pobytem na robotach przymusowych było niewystarczające wyżywienie, a właściwie jego brak ${ }^{48}$. Domicela jednak wspomina ten czas pozytywnie: „Tam dobrze nam było, bo my byli na folwarku, w majątku. Nawet 14-letnich chłopaków zabierali, tylko stare Niemki i dziadki zostawiali. Dali nam pokój. W nim byliśmy my i jeszcze jedna rodzina. Dali nas razem na jeden majątek. Co tygodnia przywozili nam jedzenie - mąkę, na kartki, margarynę, marmoladę. Potem, jak bardzo bombardowali, w Stalingradzie zaczęli się cofać, zabrali młodych. W piekarni nie było komu pracować, to dawali nam mąkę. Robiliśmy wszystko, co na polu się wykonuje - w czasie żniw

\footnotetext{
46 Chodzi tu o Prusy Wschodnie.

47 W. Jastrzębski, Warunki pracy i życia robotników przymusowych, [w:] Polscy robotnicy..., s. 109.

48 Ibidem, s. 108.
} 
stawialiśmy snopy, później woziliśmy końmi i wozem”. Po śmierci właściciela majątku jego żona otoczyła Domicelę szczególną sympatią. „Gdy baron umarł, ona stale chodziła z folwarku na podwórze, gdzie myśmy mieszkali - opowiada Rypałowska - ja gotowałam dla dziesięciu osób tam pracujących, przeważnie kaszę z łupami, pół litra mleka na osobę. Jak ona przyszła, zdziwiła się, że my to jemy. Ja raz zaklęłam po rosyjsku, a ona pyta: ty ruska? Ja mówię: da”. Okazało się, że baronowa pochodzi z Rosji ${ }^{49}$. Dała ona Domiceli materiał na okienne zasłony do mieszkania robotników (do tej pory Rypałowska robiła je z worków papierowych) i użyczyła swoją maszynę do szycia oraz uratowała Domiceli życie. Gdy Rypałowska otrzymała list, w którym pisano jej, że w rodzinie pojawiła się czerwonka i narosło wiele innych problemów, baronowa bez wahania wysłała ją do domu. „Było przed Bożym Narodzeniem 1943 r., zima, a ona mówi: ty taka tęga, ja napiszę, że ty w ciąży i dam tobie urlop nieograniczony - wspomina Domicela - jak dojedziesz do domu, to nie wracaj, ta wojna już długo nie potrwa”. Po 3 miesiącach podróży, w lutym 1944 r., Rypałowska dotarła do Uszni. Mąż pozostał w Prusach Wschodnich do 1945 r.

\section{Od przyjaźni do antagonizmu}

Krwawy konflikt ukraińsko-polski stał się bolesnym przeżyciem dla Polaków, pozostawiając w pamięci tych, którzy przeżyli, głęboki ślad i niezapomniane poczucie grozy. Według G. Hryciuka, liczba zamordowanych, rannych czy zmuszonych do ucieczki „przerosła liczbę poszkodowanych przez okupanta niemieckiego i zatarła w znacznej mierze pamięć represji radzieckich"50. Sytuacja na Kresach Wschodnich zaogniła się w połowie 1943 r. Fala pojedynczych zabójstw stała się wstępem do masowej akcji antypolskiej. W pierwszej kolejności likwidowano osoby cieszące się dużym autorytetem, liderów polskich społeczności lokalnych ${ }^{51}$. Kolejnymi na celowniku byli księża, leśnicy. Ostatecznym celem było wytępienie

49 Tożsamość „baronowej” pozostaje nieustalona. W swojej relacji Domicela Rypałowska twierdziła m.in., że baronowa pochodziła z rodziny Romanowów i jako jedyna z niej ocalała.

50 G. Hryciuk, Zmiany ludnościowe i narodowościowe w Galicji Wschodniej $i$ na Wotyniu w latach 1939-1948, [w:] Przemiany narodowościowe na Kresach Wschodnich II Rzeczypospolitej 1931-1948, Toruń 2004, s. 199.

51 G. Motyka, Ukraińska partyzantka 1942-196o. Działalność Organizacji Ukraińskich Nacjonalistów i Ukraińskiej Powstańczej Armii, Warszawa 2006, s. 369. 
144 biologiczne ludności polskiej ${ }^{52}$. Od końca 1943 r., czyli od momentu podjęcia decyzji o rozpoczęciu akcji antypolskiej w Galicji Wschodniej ${ }^{53}$, pojawiały się już przypadki mordów zbiorowych przypominających czystkę etniczną i dokonywanych metodami ludobójczymi. Działo się tak do wiosny 1945 r. ${ }^{54}$ Zbrojne oddziały ukraińskie atakowały całe, często bezbronne, wsie polskie, w których ginęła większość lub wszyscy mieszkań$\mathrm{cy}^{55}$. G. Motyka uważa, że w Galicji - w przeciwieństwie do Wołynia UPA zależało nie tyle na wymordowaniu, co na zmuszeniu Polaków za wszelką cenę do wyjazdu. Mimo to, antypolskie akcje były nierzadko nader okrutne ${ }^{56}$. Bohaterki artykułu przyznawały, że przez wiele lat dobrze układało się współżycie między Polakami a Ukraińcami. Zwróciły uwagę, że problemy jednak zaczęły się, gdy Ukraińcy zaczęli dążyć do stworzenia swojego niezależnego państwa, bez Polaków. Józefa Rudnik wspomina: „[Któregoś razu] przyjechał ksiądz ukraiński i zaczął robić różnicę. Mówił, że Ukraińcy są niby w niewoli u Polaków. Ale oni wszystko mieli, wolność, mieli swój dom kultury, kooperatywę̧5, także nie było im źle, tylko chcieli Ukrainy. I ten ksiądz wołał na kazaniu: »Ludzie, módlcie się, wszystko gotowe, ze Wschodu klamka się otworzy, będziemy mieli Ukrainę «". To wydarzenie bardzo zapadło w jej pamięć, ponieważ była wychowana w duchu patriotycznym i interesowały ją sprawy związane z Polską. D. Rypałowska opowiadała, że kiedy wróciła do domu z robót przymusowych: „już mordowali Ukraińcy" ${ }_{58}^{8}$. O mordujących banderowcach mówiły także A. Dumańska i J. Kawałko w przywołanych wyżej wspomnieniach. W powiecie Złoczów, do którego należała Usznia, w latach 1939-1946 „W wyniku eksterminacyjnej działalności ukraińskich nacjonalistów spod znaku OUN, UPA, SKW i militarnych jednostek ukraińskich w służbie Niemiec hitlerowskich" zginęły co najmniej 942 osoby ${ }^{59}$.

52 Ibidem.

53 Idem, Od rzezi wotyńskiej do akcji „Wisła”. Konflikt polsko-ukraiński 1943-1947, Kraków 2011, s. 220.

54 G. Hryciuk, Przemiany narodowościowe i ludnościowe..., s. 244.

55 Idem, Przemiany ludnościowe w Galicji..., s. 60.

56 G. Motyka, Od rzezi..., s. 254-255.

57 Kooperatywa „Jedność” - zob. Księga adresowa Polski..., s. 1714.

58 Rozmówczyni nie wracała już do wątku konfliktu polsko-ukraińskiego.

59 H. Komański, Sz. Siekierka, op. cit., s. 516-517. 
Domicela Domańska, Domicela Rypałowska i Józefa Kawałko zachowały w pamięci również uczucie głodu. Domicela Domańska mówiła: „Jednego roku był taki głód, że z liści buraków zupę gotowano". J. Kawałko dodaje: „Ten głód to było coś okropnego. Nie było ani pokrzyw, ani lebiody, bo ludzie wszystko zjedli. Kto umiał chodzić po drzewach, to się choć czereśni najadł. Potem zostawały tylko odchody z pestkami. Były koło nas takie piękne łąki, a tam bardzo dużo szczawiu rosło. Ja nazbierałam całą torbę i gotowałam barszcz. Piekłam też placki z żyta. Bywało, że my z bratem 3 dni nie jedliśmy". W latach 1941 i 1942 dochodziło nawet do przypadków śmierci z głodu ${ }^{60}$.

Przesiedlenia

W lipcu 1944 r. Polski Komitet Wyzwolenia Narodowego podpisał z rządem ZSRR układ o polsko-radzieckiej wschodniej granicy państwowej ${ }^{61}$. Miała ona przebiegać z nielicznymi korektami według tzw. linii Curzona. W rezultacie tych postanowień, zapadły decyzje o przesiedleniu ludności polskiej, ukraińskiej, białoruskiej, litewskiej zarówno do Polski, jak i z Polski do odpowiednich republik radzieckich. W umowie o wzajemnej „ewakuacji” ludności, zawartej między PKWN a Radą Komisarzy Ludowych USRR z września 1944 r., ustalono, że akcja ma być dobrowolna. Ponadto przesiedlający się mieli prawo do przewiezienia inwentarza ruchomego. Wraz z przesiedlającymi się mogły wyjechać rodziny (współmałżonkowie, dzieci, rodzice, wnuki ze wspólnego gospodarstwa domowego), a dzieci powyżej czternastu lat mogły same zadecydować o wyjeździe. Przesiedleńcy musieli złożyć dokumenty o narodowości. Jednak nie sprecyzowano trybu ich weryfikacji ${ }^{62}$. W rzeczywistości decydowała o tym praktyka ${ }^{63}$. $\mathrm{Na}$ Kresach południowo-wschodnich na przesiedlenie decydowały się osoby,

60 G. Hryciuk, Przemiany ludnościowe w Galicji..., s. 60.

61 W. Borodziej, S. Ciesielski, J. Kochanowski, Wstęp, [w:] Przesiedlenie ludności polskiej z Kresów Wschodnich do Polski 1944-1947. Wybór dokumentów, red. S. Ciesielski, Warszawa 1999, s. 15.

62 G. Hryciuk, Przesiedlenia Polaków z Kresów Wschodnich II RP 1944-1946, [w:] Ziemie Zachodnie - historia i perspektywy, red. W. Kucharski i G. Strauchold, Wrocław 2011, s. 103-104.

63 S. Ciesielski, Kresy Wschodnie II Rzeczypospolitej i problemy identyfikacji narodowej, [w:] Przemiany narodowościowe na Kresach Wschodnich II Rzeczypospolitej 19311948, red. S. Ciesielski, Toruń 2004, s. 46. 
146 które określiły się jako Polacy. Było to na rękę stronie ukraińskiej. Władze USRR kontynuowały przymus, aby pozbyć się ludności polskiej ze swojego terytorium. Był nim terror ukraińskiego podziemia, szczególnie nasilony na wsiach. Z kolei na Kresy Wschodnie przesiedlano Ukraińców, którzy mieszkali w Polsce, w jej nowych, powojennych granicach. S. Ciesielski podaje, że od października 1944 do końca 1946 r. przesiedlono z Polski do USRR 482,9 tys. osób, z czego ponad 2/3 osiedlono w zachodnich obwodach USRR, czyli na Kresach Wschodnich II Rzeczypospolitej ${ }^{64}$. „W 1944 r. już Ruskie przyszli do nas jako »przyjaciele« - mówi Józefa Rudnik - jeszcze rok byliśmy z nimi. Musieliśmy się stamtąd zabierać, my nie pojechaliśmy z ochotą, na nasze gospodarki przyjeżdżali Ukraińcy z Rzeszowa. Jacy oni Ukraińcy, jak nie mówili po ukraińsku, tylko po polsku".

Bardzo wielu mieszkańców Kresów Wschodnich miało dylemat, czy pozostać na ojcowiźnie, czy jechać w nieznane. Jak podkreślała Józefa Rudnik, mieszkańcy Uszni nie wyjeżdżali z ochotą. Z wyjazdem wiązały się wielkie emocje i przeżycia. „Była bieda, ale ludzie, jak jechali, to płakali - wspomina Adela Dumańska - do tej pory, jak się jedzie na Usznię, to taki sentyment czuć. To była piękna wieś. [...] Ludzie jechali w nieznane. Nikt nie wiedział, co to będzie, nie było radia, telewizji, kazano się zabierać i jechać w ciemno, więc każdy się bał, dokąd zajedzie. Ktoś zaintonował jakąś pieśń religijną czy patriotyczną, to zaraz cały transport ludzi śpiewał. [...] To było wielkie wzruszenie - mówi - tak żegnaliśmy się ze swoją wsią. Te nabożne pieśni śpiewaliśmy aż do Lwowa. Ludzie płakali. Pamiętam też, że mój dziadek, Feliks Domański, wcale nie chciał wyjeżdżać na zachód, bo mówił, że czeka na syna, Łukasza, bo go Niemcy zabrali i on wróci. A myśmy już wiedzieli, że on nie żyje...”.

W umowie między państwem polskim a Ukraińską SRR przewidziano na rejestrację okres od 15 września do 15 października 1944 r. Sam transfer miał potrwać od 15 października 1944 r. do 1 lutego 1945 r., ale praktyka wymusiła przedłużenie akcji przesiedleńczej do końca $1945 \mathrm{r}^{65}$ Według relacji, przesiedleńcy z Uszni wyjechali trzema transportami w 1945 r. Analiza dokumentów PUR wskazuje jednak, że tych transportów było więcej niż

64 Ibidem, s. 51; G. Hryciuk, M. Ruchniewicz, B. Szaynok, A. Żbikowski, Wysiedlenia, wypędzenia i ucieczki 1939-1959. Atlas ziem Polski. Polacy, Żydzi, Niemcy, Ukraińcy, Warszawa 2008, s. 211.

65 W. Borodziej, S. Ciesielski, J. Kochanowski, op. cit., s. 14-16. 
trzy. Bardziej zasadna wydaje się informacja o podróży w trzech kierunkach ${ }^{66}$ : na Górny Śląsk, Pomorze i na Dolny Śląsk, gdzie kierowano najwięcej transportów ${ }^{67}$. Ogółem w 1945 r. przesiedlono z Ukrainy do Polski 511877 osób, z czego 6o,1\% stanowili mieszkańcy wsi ${ }^{68}$. Jeśli chodzi o dane dotyczące Galicji Wschodniej, to w latach 1944-1946 wyjechało 618,2 tys. Polaków, w tym 251,5 tys. z Podola ${ }^{69}$. Zanim jednak się to stało, każda osoba musiała się zarejestrować, pobrać kartę ewakuacyjną i zgłosić do transportu. Przesiedleńcy mogli ze sobą zabrać część dobytku o wadze do 2 ton na rodzinę, m.in. odzież, obuwie, pościel, żywność, sprzęt domowy, gotówkę do wysokości 1000 rubli na osobę oraz bydło i ptactwo domowe ${ }^{70}$. Józefa Kawałko opowiada: „Najpierw trzeba było wyrobić kartę ewakuacyjną, zapisać, ile majątku się zostawiło i dopiero czekać na wyjazd. Jeszcze trzeba było 2 tygodnie w Złoczowie czekać. A mój brat był wtedy w wojsku. »Nic nie bierz - pisał - tylko bierz Bronka i moje książki (bardzo o nie dbał), tam na zachodzie wszystko jest i ubrania, i jedzenie«. On był na froncie, Niemcy uciekali od Ruskich i jedzenie zostawiali na stołach, ale w to nikt nie wierzył. Kto by wiedział, że tam wszystko jest, do głowy nie przyszło! Mówię do ciotki: »ja jadę«. Miałam 15 lat, poszłam do Ukraińca zapytać, czy mnie zawiezie do Złoczowa. Zawiózł mnie za koc bardzo ładny. Meble sprzedałam Ukraince sąsiadce za parę groszy, bo wszystko było biedne. Mało rzeczy ze sobą wzięłam, bo my też byliśmy biedni”.

Rodzice Domiceli Domańskiej przywieźli z Uszni konia i dwie krowy. Zabrali stamtąd także wóz z szafą i pługiem. Mieszkańcy Uszni zabrali ze sobą z tamtejszego kościoła dzwon, sygnaturkę (mały dzwonek), konfesjonał, figury świętych.

66 Por. D. Sula, Działalność przesiedleńczo-repatriacyjna Państwowego Urzędu Repatriacyjnego w latach 1944-1951, Lublin 2002, mapa nr 2, s. 201.

67 W rezultacie zarządzenia Zarządu Centralnego PUR z 30 kwietnia 1945 r. wszystkie transporty ze Wschodu miały być kierowane na Ziemie Zachodnie i Północne, szczególnie na Śląsk Dolny i Opolski. Zob.: M. Hejger, Przekształcenia narodowościowe na Ziemiach Zachodnich i Północnych Polski w latach 1945-1959, Słupsk 2008, S. 42.

68 W. Borodziej, S. Ciesielski, J. Kochanowski, op. cit., s. 29.

69 G. Hryciuk, M. Ruchniewicz, B. Szaynok, A. Żbikowski, op. cit., s. 85.

70 M. Hejger, op. cit., s. 41; W. Borodziej, S. Ciesielski, J. Kochanowski, op. cit., s. 15. 
„W lipcu 1945 roku wyjechaliśmy - wspomina Domicela Rypałowska - jechaliśmy trzy tygodnie, dotarliśmy do Laskowic [na Dolnym Śląsku przyp. N.J.]". Józefa Rudnik dodała, że w Złoczowie czekali na podstawienie pociągu w prowizorycznie postawionych budach. Z kolei Adela Dumańska tak zapamiętała ten czas: „W Złoczowie czekaliśmy tydzień czasu na pociąg. W lipcu wyjechaliśmy, podróż trwała miesiąc. Jechaliśmy trzecim, ostatnim transportem. Pierwszy transport na Górny Śląsk był dwa tygodnie wcześniej. W pierwszym transporcie jechały matki z dziećmi, których mężowie byli na wojnie".

Transport w dużej mierze składał się z wagonów odkrytych, tzw. węglarek $^{71}$. Często przesiedlenia te odbywały się w nieludzkich warunkach ${ }^{72}$. Przyczyną był brak wystarczającej ilości środków transportu, wyżywienia, możliwości utrzymania higieny, ogólny $\operatorname{chaos}^{73}$. Był to czas końca wojny i pierwszych miesięcy pokoju, po obu stronach granicy były ogromne zniszczenia, a życie społeczne, gospodarcze i administracyjne dopiero się kształtowało. Brakowało wielu podstawowych środków, a transport, łączność i aprowizacja podporządkowane były jeszcze powrotnym przemieszczeniom wojsk ${ }^{74}$. „Myśmy jechali w wagonach towarowych i to bez dachu opowiada Józefa Rudnik - jechało nas 4 rodziny, wszystkich 17 osób i w tym samym wagonie było zboże, krowy i koń. Przez cały czas podróży nie było gdzie się wykąpać. Spaliśmy w tych samych ubraniach. Po drodze była rzeka. Wszyscy poszli się do niej kąpać. A tam jeszcze trupy leżały, bo dopiero front się skończył. Popraliśmy bieliznę, wykąpaliśmy się. Wróciliśmy do wagonów, a po jakimś czasie strasznie obsiadły nas wszy. To było okropne, zlikwidowaliśmy je dopiero w Domaniowie”. Adela Dumańska pamięta podobną historię: „Ksiądz jechał w wagonie obok, czarną sutannę codziennie trzepał. Zajechaliśmy nad rzekę, mężczyźni chcieli się obmyć, dzieci były miesiąc czasu nie kąpane, a były też noworodki, w Złoczowie nawet jedna kobieta rodziła”. „Kiedy przyszły te wagony, nas było 3 rodziny w jednym wagonie, ta bez męża, ta z małym dzieckiem, ta chora, ja sama musiałam

71 W. Borodziej, S. Ciesielski, J. Kochanowski, op. cit., s. 35.

72 P. Ther, Wypędzeni w sowieckiej strefie okupacyjnej/NRD i Polsce. Próba uporządkowania historii, [w:] Kompleks wypędzenia, red. W. Borodziej, A. Hajnicz, Kraków 1998, S. 220-221.

73 Ibidem, s. 33; D. Sula, op. cit., s. 65.

74 W. Borodziej, S. Ciesielski, J. Kochanowski, op. cit., s. 32. 
ładować co nasze - mówi Józefa Kawałko - jak jechaliśmy to ani ugotować, było ciężko, ale dawaliśmy radę. Cały łan rabarbaru był po drodze, narwałam pełno i przyniosłam, to gotowaliśmy kluski na rabarbarze. Potem melasa była, chleb nią smarowaliśmy, cukrowaliśmy kawę” „Na Wschodzie, na Uszni załadowaliśmy na wóz wszystko, co mieli - opowiada Adela Dumańska. - Babcia z ogrodu warzyw nazrywała, z kuchni blaty wzięliśmy, żeby po drodze gotować. Ludzie nam przekazywali, co musimy brać, bo już wiedzieli jak transport wygląda. Wagony były towarowe. W jednym wagonie było bydło i byli ludzie. Gdzie pociąg stał, to ci, co mieli blat, kładli go na cegły i tak mleko gotowali, bo nie było, co jeść. Jak się pociąg zatrzymał, a siano na łące było, to ludzie zbierali”.

\section{W poszukiwaniu lokalnej „ojczyzny”}

Transport z mieszkańcami Uszni dotarł do Laskowic, dolnośląskiej miejscowości w powiecie oławskim, która po niemiecku nazywała się Markstädt. Tam ludzie spędzili jeszcze kilka dni. Przesiedleńcy powinni byli trafić na koniec podróży do punktu etapowego, a stamtąd być przewożeni do miejsca osiedlenia. Zdarzało się jednak, tak jak w omawianym przypadku, że wyładowywano ich na stacji albo w polu ${ }^{75}$. Domicela Rypałowska wspomina, że wyładowali ich na łące w Markstädt. Od maszynisty dowiedzieli się, że jest miejsce do zamieszkania w okolicy Legnicy. Było to jednak za daleko i musieli szukać miejscowości w pobliżu, na własną rękę. „Cały czas była mowa, że my wszyscy zamieszkamy razem w jednym miejscu, bo jak nie, to nie wychodzimy z wagonów ${ }^{76}$ - mówi Rypałowska. - »Niech wiozą nas z powrotem do domu « - groziliśmy. Ksiądz [Eugeniusz] Nowak z mężczyznami na koniach pojechali szukać, ale co wrócili wieczorem, to mówili, że nie ma takiej wsi dużej, nie ma kościoła. Ludzie zaczynali umierać:

Ibidem, s. 38 .

76 To charakterystyczne zjawisko zauważył J. Burszta: „Repatrianci wyjeżdżali do Polski specjalnymi transportami kolejowymi przewożącymi ludność z jednych okolic. Wyjeżdżali więc oni całymi zwartymi grupami lokalnymi i podobnie zwarcie i grupowo osadzali się na Ziemiach Zachodnich. Zdarzało się, że dany transport długo krążył po Ziemiach Zachodnich w poszukiwaniu takiego miejsca, gdzie cała grupa mogłaby razem zamieszkać. Poszukiwano nawet zewnętrznych podobieństw miejscowości nowej do dawnej. Ułatwiało to m.in. szybką asymilację do nowego środowiska. J. Burszta, Kategorie ludności i ich typ kulturowy, [w:] Przemiany społeczne na Ziemiach Zachodnich, red. W. Markiewicz, P. Rybicki, Poznań 1967, s. 165. 
dziecko, potem kobieta z mojego wagonu. Wreszcie przyjechał jakiś urzędnik z PUR-u i mówi, że nie będziemy tu koczować. Jest wioska, ostatnia w powiecie, ale $30 \mathrm{~km}$ stąd. Decyzja należy do nas. Wtedy mężczyźni rozłożyli wozy, pojechali sprawdzić i mówią, że wioska duża, ładna, niezbombardowana, tylko pełno wojska ruskiego. Ale żołnierze z kolei powiedzieli, że jak przyjdą Polacy, to oni pójdą stamtąd. Był we wsi też niemiecki ksiądz. Kto miał wóz zaczął jechać".

Wieś, do której wyruszyli, nazywała się Thomaskirch, wówczas po polsku Domajowice, dziś Domaniów ${ }^{77}$. Józefa Rudnik i Domicela Domańska wspominały, że argumentami za osiedleniem się w Thomaskirch były dobre ziemie i istniejący tam kościół: „[...] gdzie kościól, to tam musi być swój lud” - tłumaczyła Adela Dumańska. Józefa Rudnik wspominała: „ksiądz Nowak wsiadł na wóz i pojechał tutaj domów szukać. Przyjechał i powiedział: wy się tu nie rozładowujcie, tylko jedzcie do Thomaskirch, tam jest dobra ziemia, tam jest kościół, co wy na tych piachach będziecie robić?" Glebę w tej okolicy uważali za czarnoziemy, co przypominało im te zostawione na Wschodzie i było interpretowane jako znak, że mogą się tu osiedlić. Podobieństwo krajobrazu do ich stron ojczystych ułatwiało Kresowianom osiedlonym w Domaniowie adaptację w nowym miejscu zamieszkania ${ }^{78}$.

Przesiedleńcy podążali do Thomaskirch pieszo lub wozami, z przywiezionym z Uszni dobytkiem. „Szliśmy z tych Laskowic piechotą, na Odrze był most drewniany, ja swoje krówki prowadziła - wspomina Józefa Rudnik - patrzymy, a tutaj zboża leżą. Musiało być bardzo suche lato, że to zboże nie zgniło. A w Oławie byli już ludzie. Widzieliśmy, jak idą z kościoła poubierani, a my tacy biedni, brudni - krowy w wagonach pod siebie robiły. Do Domaniowa szliśmy jeden dzień - wyszli rano i na popołudnie byliśmy na miejscu". Domicela Domańska pamięta, że z Laskowic do nowej wsi jechali wozem zaprzęgniętym w konie. Oprócz tego dobytku z rodzinnej miejscowości przywieźli także sierp i pług. Józefa Kawałko z Laskowic

77 W monografii Domaniowa podano, że zdecydowana większość osadników w Domaniowie i okolicach pochodziła z Kresów Wschodnich, tj. 85,2\%, głównie z województw tarnopolskiego (69,8\%) i lwowskiego (8,5\%). Przybysze z Polski Centralnej stanowili 10,06\% osadników. Największe zwarte grupy przybyły ze wsi Usznia i Sokolnik. Domaniów. Przeszłość i wspótczesność gminy, red. R. Gładkiewicz, Wrocław 200o, s. 23.

78 M. Hejger, op. cit., s. 60. 
trafiła na początku do wsi sąsiadującej z Thomaskirch: „Zastanawialiśmy się, jak my z tych Laskowic dotrzemy do Domaniowa. Wyszłam na drogę, a tam, jechał Niemiec, ogromnym wozem! U nas wszystko malutkie było. Siadłam na wóz, zabrał mnie i brata i to, co miałam. Zajechaliśmy aż do Skrzypnika"79. Po dwóch latach przeprowadziła się do Domaniowa.

Kresowianie wyraźnie odróżniali się od pozostałej części ludności polskiej Ziem Zachodnich oraz przebywających tu jeszcze Niemców, w szczególności tym, że byli najbiedniejsi ${ }^{80}$. W wyniku słabego rozwoju gospodarczego wschodnich województw przedwojennej Polski, Kresowian cechowało zapóźnienie cywilizacyjne. Na nowo osiedlonych ziemiach używali przywiezionych drewnianych narzędzi rolniczych, zboże żęli sierpami. Odrębność kulturowa, językowa, materialna powodowała trudności w adaptacji i asymilacji z pozostałą ludnością polską przybyłą na te ziemie oraz kształtowanie się stereotypów o Kresowianach, m.in. jako o złych gospodarzach ${ }^{81}$.

Adela Dumańska twierdzi, że do Domaniowa przybyła z rodziną 14 sierpnia, bo 15 - w święto Wniebowzięcia Najświętszej Maryi Panny - po raz pierwszy była w domaniowskim kościele. Według zapisów w ewidencji repatriantów dane Adeli i jej rodziny zostały umieszczone w rejestrze pod datą 25 sierpnia 1945 r. $^{82} \mathrm{Z}$ tego wynika, że w Domaniowie mogła być najszybciej 25 sierpnia. W jej pamięci zachowało się skojarzenie ze świętem, ale - biorąc pod uwagę ewidencję - zapewne chodziło o święto Matki Boskiej Częstochowskiej obchodzone w dniu 26 sierpnia. Z rejestrów PUR-u dotyczących transportów i ewidencji repatriantów wynika, że pociągi z mieszkańcami Uszni docierały do punktu etapowego Oława (Laskowice) codziennie lub co kilka dni. Według dokumentów najwcześniej spośród respondentek odnotowana została Domicela Domańska z rodziną - 3 sierpnia $1945 \mathrm{r}^{83}$, później wspomniana już Adela Dumańska, potem Domicela Rypałowska - 7 września $1945 \mathrm{r}^{84}$, następnie Józefa Rudnik - 13 września 1945 r. ${ }^{85} \mathrm{~W}$ rejestrze

79 W Skrzypniku osiedliło się dużo Kresowian z miejscowości Zaleszczyki.

80 M. Hejger, op. cit., s. 60.

81 Ibidem, s. 6o-61.

82 Archiwum Państwowe we Wrocławiu (dalej: APWr.), Państwowy Urząd Repatriacyjny (dalej: PUR), sygn. 1611, k. 13, pozycja (dalej: poz.) 6033.

83 APWr., PUR, sygn. 1610, k. 4, poz. 3574.

84 APWr., PUR, sygn. 303, k. 155, poz. 7863.

85 APWr., PUR, sygn. 1612, k. 20, poz. 8717. 
zapisano, że przyjechały z Uszni i kierują się do Domajowic. Józefa Kawałko zarejestrowana została pod datą 9 listopada $1945 \mathrm{r}^{86}$ jako osoba przybywająca z Uszni i kierująca się do Rówieńczyna (dziś Skrzypnik).

\section{Osiedlenie w Domaniowie}

Domaniów to osada kościelna o średniowiecznej metryce. Wzmiankowana była już w dokumencie papieskim z 1193 r. jako „ecclesia Thome”. W roku 1300 wieś wymieniana była pod nazwą Domaskirche lub Thomaskirche ${ }^{87}$. W 1783 r. w Domaniowie znajdował się jeden kościół katolicki z plebanią, szkoła, 430 mieszkańców, katolików, mówiących w języku polskim i niemieckim ${ }^{88}$. W 1845 r., oprócz wymienionych budynków, istniały dwie gorzelnie, jeden wiatrak, jedna gospoda, tłocznia oleju, w 109 domach mieszkało 761 osób, w tym 58 ewangelików. We wsi działało trzynastu rzemieślników i dziewięciu handlarzy ${ }^{89}$. W 1885 r. powierzchnia wsi wynosiła 858 ha, z czego grunty orne stanowiły 814 ha, łąki 13 ha, drzewostan 2 ha90. W 1910 r. otworzono kolejkę wąskotorową, która łączyła wieś z Oławą i Borkiem Strzelińskim ${ }^{91}$. W Domaniowie istniał dworzec kolejowy (do 1963 r.), dom urzędnika kolejowego oraz niewielki zakład naprawy taboru. Działały przewozy towarowe i osobowe ${ }^{92}$. Istotną rolę w domaniowskiej społeczności odgrywali katoliccy proboszczowie (Hugo Hoffman, Berthold Dittrich, Karl Pastuszyk), wieloletni sołtys wsi Paul Maruschke (inicjator budowy wspomnianej linii kolejowej) oraz siostry szarytki, opiekujące się chorymi, małymi dziećmi i dziewczętami, prowadząc własną ochronkę ${ }^{93}$.

86 APWr., PUR, sygn. 1617, k. 58, poz. 14707.

87 Zob. Katalog zabytków sztuki w Polsce. Województwo wrocławskie (dolnośląskie). Powiat oławski, red. E. Kołakiewicz, z. 4, Warszawa 2013, s. 18-19.

88 http://klauskunze.com/ohlau/orte/thomaskirch.htm (dostęp: 16 X 2014 r.).

89 Ibidem.

90 Ibidem.

91 Katalog zabytków sztuki w Polsce..., s. 19; Domaniów. Przeszłość..., s. 19.

92 Ibidem.

93 Domaniów. Przeszłość..., s. 19-20. Podobne informacje na temat Domaniowa można znaleźć w czterech artykułach na łamach „Gazety Powiatowej - Wiadomości Oławskie" 20oo, nr 40 (386); 41 (387); 42 (388); 43 (389). 
Na skutek I wojny światowej miejscowa społeczność odniosła duże straty, ponieważ poległo lub zaginęło 52 mężczyzn. Ich nazwiska umieszczono na marmurowej tablicy pamiątkowej, znajdującej się do dziś przy kościele ${ }^{94}$. W 1935 r. było 1091 mieszkańców, a w 1939 - $1075^{95}$. Do 1945 r. wieś najczęściej wzmiankowana jest jako Thomaskirch, a po tym roku jako Domajowice ${ }^{96}$.

Z relacji seniorek dowiadujemy się, że Thomaskirch uniknęło większych zniszczeń wojennych. W dokumentach Wrocławskiego Urzędu Wojewódzkiego dostępnych w Archiwum Państwowym znajduje się informacja, iż w gminie Domaniów na skutek działań wojennych zostało zniszczonych 25\% gospodarstw z budynkami mieszkalnymi ${ }^{97}$. Józefa Rudnik i Domicela Domańska pamiętają, że Domaniów był wioską zadbaną, choć niektóre domy były częściowo pozawalane. Większe szkody powodował pobyt żołnierzy radzieckich. „Domaniów nie był zniszczony, ale zapaskudzony tym wojskiem radzieckim" - wspomina Adela Dumańska. Podobne wspomnienia ma Domicela Rypałowska: „[...] Dół był zamknięty, a na górze byli Sowieci, mieli w stajni dużo koni, pilnowali. Ruskie potem się wynieśli, za 2 dni nie było już nikogo. Na górze pełno ptasich odchodów, poduszki porozpruwane, pióra latają". O zniszczeniach dokonanych przez radzieckich wojskowych mówiła też J. Kawałko: „W domaniowskim domu podłogi były połamane, ruskie połamali. Nawet w spiżarce jest taki dół. Niemcy zakopali tam rzeczy, ale Ruskie i tak znaleźli i zabrali. Ruskie w szopie, stojącej obok domu, trzymali wszystkie swoje rzeczy". W ocenie wielu badaczy pobyt wojsk radzieckich wpłynął destrukcyjnie i destabilizująco na proces osiedlania we wszystkich jego aspektach ${ }^{98}$. Było to widoczne m.in. w bezkarnej

94 Ibidem, s. 20.

95 Einwohnerbuch Stadt und Kreis Ohlau, Eschenhagen 1935, s. 254; Amtliches Gemeindeverzeichnis für das Deutsche Reich auf Grund der Volkszählung 1939, [w:] Statistik des Deutschen Reichs, t. 550, Berlin 1941, s. 83.

96 Katalog zabytków sztuki w Polsce..., s. 19.

97 APWr., Urząd Wojewódzki Wrocławski (dalej: UWW), sygn. IX/69, k. 11.

98 M. Hejger podsumowuje stan badań na ten temat: M. Hejger, op. cit., s. 29-3o. Zob. też: J. Hytrek-Hryciuk, „Rosjanie nadchodzą!” Ludność niemiecka a żotnierze Armii Radzieckiej (Czerwonej) na Dolnym Śląsku w latach 1945-1948, Wrocław 2010, S. 142 . 
przestępczej działalności żołnierzy i oficerów radzieckich oraz zawłaszczaniu i wywożeniu do ZSRR mienia poniemieckiego ${ }^{99}$. J. Misztal pisze również, że do 16 sierpnia 1945 r., czyli do podpisania „ostatecznej umowy w sprawie granic wschodnich oraz porozumienia o podziale niemieckich reparacji między ZSRR a Polską, ziemie zachodnie i północne traktowane były przez władze radzieckie jako terytorium podbite, z którego wywożono tzw. łup wojenny"10o.

Kiedy nowi osadnicy dotarli do Domaniowa w 1945 r., nie zastali jeszcze ustabilizowanej i zorganizowanej administracji polskiej ${ }^{101}$. Pod koniec wojny, na podstawie porozumienia między PKWN a rządem ZSRR z 26 VII 1944 r., na terenie dawnych ziem Rzeczypospolitej zaczęła powstawać radziecka administracja wojenna poprzez powoływanie tzw. komendantur ${ }^{102}$. W chwili rozpoczynania ich działalności (na Dolnym Śląsku po 22 stycznia 1945 r.) nie było jeszcze polskiej administracji, dlatego powstające

99 M. Hejger, op. cit., s. 3 o.

100 J. Misztal, Przesunięcie Polski na zachód, [w:] Kompleks wypędzenia, red. W. Borodziej i A. Hajnicz, Kraków 1998, s. 78; M. Ruchniewicz, Lata 1945-1948, [w:] Dolny Ślask. Monografia historyczna, red. W. Wrzesiński, Wrocław 2006, s. 638-639.

101 Na podstawie dokumentów można stwierdzić, że administracja polska funkcjonowała przynajmniej od 1 sierpnia $1946 \mathrm{r}$. W Zestawieniu $n r 1$ osiedlonych rodzin na dzień 1 sierpnia 1946 r. w miejscowości Domajowice mieszkali milicjant Koziarz Wojciech, milicjant Zawierucha Jan, urzędnik Kiełczewski Józef, urzędnik Wzorek Ludwik, Strąk Bolesław - sekretarz. Nie jest wprost napisane, że byli zatrudnieni w gminie Domajowice, ale można się tego domyślać. Zamieszczono natomiast informację, że wszystkie wymienione osoby to przesiedleńcy, a nie repatrianci (wyjątek stanowią dane dotyczące Józefa Kiełczewskiego, prawdopodobnie omyłkowo wpisano, że to repatriant, bo został osiedlony na podstawie dokumentów PUR), użytkowanie zajętego gospodarstwa wprowadzono na podstawie decyzji PUR lub karty przesiedleńca, a nie ewakuacyjnej, dlatego najprawdopodobniej pochodzili z centralnej Polski. APWr, PUR, sygn. 59o, k. 489-49o. Zestawienie nr 1 osiedlonych rodzin na dzień 1 sierpnia 1946 r., Gromada Domajowice, gmina Domajowice, powiat Otawa, [w:] Powiatowy Oddziat PUR. Imienne spisy osadników osiedlonych w powiecie Oława, Oleśnica. Spis osiedlonych od nr 1-677, $1946 r$. W monografii Domaniowa podano, że pierwsi przedstawiciele polskiej administracji przybyli do Domaniowa 12 czerwca 1945 r., kiedy powstał posterunek milicji. Domaniów. Przeszłość..., S. 21.

102 J. Misztal, op. cit., s. 71-72. 
komendantury oparły się na niemieckiej strukturze administracyjnej. Przekazywanie władzy administracji polskiej odbywało się stopniowo od kwietnia 1945 r. ${ }^{103}$, a w lipcu 1945 r. pełnomocnikowi okręgowemu Dolnego Śląska przekazano już 57 miejscowości ${ }^{104}$.

W pamięci respondentek zachował się polski funkcjonariusz, którego nazwisko podawano w kilku wersjach (Koziek, Koziarz ${ }^{105}$ ). Wspominano także o polskim wójcie, ale nie pamiętano nazwiska. Według Domiceli Domańskiej, urzędował w tym czasie jeszcze niemiecki sołtys. Relacje o sposobie zajmowania domów przez nowo przybyłych różnią się. Nie wiadomo więc do końca, czy ktoś przydzielał dom rodzinie, czy rodzina zajmowała dom wedle upodobania. Pewnych informacji na ten temat dostarczają dokumenty Wydziału Osiedleńczego Urzędu Wojewódzkiego zgromadzone w Archiwum Państwowym. W sprawozdaniu z przebiegu akcji przesiedleńczej w okresie do 15 sierpnia 1945 r. zanotowano, że: „Stworzone zostały Komitety Osiedleńcze w każdej wsi, których zadaniem jest zorganizowanie samopomocy i jak najszybsze ulokowanie po gospodarstwach i warsztatach pracy osiedleńców"106. Domicela Domańska relacjonowała: „jak tu przyjechali, był sołtys niemiecki, pchał gdzie Niemcy byli. My byli na górze, a Niemcy na dole". Domicela Rypałowska zapamiętała, że: „żadnej władzy nie było, a później dopiero jakaś władza przyjechała [...] było wojsko ruskie, jeden polski milicjant i Koziarz i wójt był spod Częstochowy. Gdzie sobie kto znalazł dom, tam zostawał, wchodził i już. [...] Zajechaliśmy koło kościoła. Tam wyszedł wojskowy i mówi wybierajcie, który chcecie”. Józefa Rudnik wspominała: „my tu przyjechali i był tu posterunek i był komendant Koziek. To był cały bóg, on tu rządził. My nie wiedzieliśmy, że możemy iść, gdzie chcemy, tylko on tutaj musiał

103 B. Pasierb, Migracja ludności niemieckiej z Dolnego Śląska $w$ latach 1944-1947, Wrocław-Warszawa-Kraków 1969, s.42.

104 J. Misztal, op. cit., s. 78.

105 Właściwe nazwisko to Koziarz. W Zestawieniu osiedlonych rodzin w Domajowicach na dzień 1 sierpnia 1946 r. wpisany został Koziarz Wojciech oraz dodatkowe dane m.in.: nr domu 18, zawód obecnie wykonywany milicjant, przesiedlony na podstawie karty przesiedlenia. APWr, PUR, sygn. 590, k. 489, poz. 37. Zestawienie nr 1 osiedlonych rodzin na dzień 1 sierpnia 1946 r., Gromada Domajowice, gmina Domajowice, powiat Otawa, [w:] Powiatowy Oddziat PUR. Imienne spisy osadników osiedlonych w powiecie Otawa, Oleśnica. Spis osiedlonych od nr 1-677, 1946 r.

106 APWr., UWW, sygn. IX/29, k. 8, Sprawozdanie Referatu Osiedleńczego Obwodu (Miasta) nr 1 w Otawie z przebiegu akcji osiedleńczej w terenie za okres od-do 15. VIII. b.r. 
pokazać. [...] Wójt przyjechał - Moryl ${ }^{107}-$ z centralnej Polski, najpierw milicja rządziła, sołtys był nasz Mikoda"108. Zarówno z relacji, jak i z dokumentów PUR wiadomo, że w Domaniowie osiedlały się także osoby z centralnych województw Polski, zniszczonych działaniami wojennymi lub przeludnionych ${ }^{109}$. Według umów o wymianie ludności przesiedleńcy ze Wschodu - w przeciwieństwie do tych z terenów centralnej Polski mieli prawo do otrzymania rekompensaty za pozostawione na Wschodzie gospodarstwo. Podstawą do osiedlenia tzw. repatriantów były ich karty ewakuacyjne oraz opis pozostawionego mienia, a w przypadku ich braku - orzeczenia PUR ${ }^{110}$. Na podstawie kart ewakuacyjnych rodzinom Adeli Dumańskiej (5 osób) i Domiceli Domańskiej (5 osób) przyznano po 10 hektarów ziemi, Józefie Rudnik (rodzina dwuosobowa) i Józefie Kawałko (rodzina trzyosobowa) przydzielono po 2 hektary ziemi. Sześcioosobowej rodzinie, w której mieszkała Domicela Rypałowska, przyznano 10 hektarów, ale na podstawie orzeczenia PUR ${ }^{111}$. Zgodnie z forsowanymi

107 W dokumentach PUR z 1946 r. w spisie osiedlonych Moryl Aleksander - przesiedleniec - wpisany został jako rolnik, nie ma podanej jego innej funkcji. Podpisy wójta są nieczytelne. Natomiast w dokumentach tych widnieje podpis sołtysa, którym był Mikoda Józef, co zgadza się z relacją. APWr, PUR, sygn. 59o, k. 489-49o. Zestawienie nr 1 osiedlonych rodzin na dzień 1 sierpnia 1946 r., Gromada Domajowice, gmina Domajowice, powiat Otawa, [w:] Powiatowy Oddział PUR. Imienne spisy osadników osiedlonych w powiecie Otawa, Oleśnica. Spis osiedlonych od nr 1-677, 1946 r.

108 Według monografii Domaniowa pierwszym wójtem gminy Domaniów został Józef Mikoda, ale w świetle dokumentów, o których pisałam wyżej, ta informacja nie wydaje się prawdziwa. Domaniów. Przeszłość..., s. 21.

109 D. Sula, op. cit., s. 93-94.

110 W. Borodziej, S. Ciesielski, J. Kochanowski, op. cit., s. 45-47.

111 W dokumentach PUR wymieniano z imienia i nazwiska tylko głowę rodziny, podano m.in. ilość osób utrzymujących się z przyznanego gospodarstwa i jego wielkość, nr domu, w którym zamieszkała rodzina oraz podstawę, na jakiej przypisano ziemię (np. karta ewakuacyjna bądź orzeczenie PUR). Wielkość przydzielonego gospodarstwa w Zestawieniu nr 1 osiedlonych rodzin na dzień 1 sierpnia 1946 r. dla rodziny Domiceli Domańskiej należy szukać pod nazwiskiem Wiktor Wodziński (ojciec Domiceli, pozycja w Zestawieniu nr 76), dla rodziny Domiceli Rypałowskiej pod nazwiskiem Marceli Kłak (ojciec Domiceli, pozycja w Zestawieniu nr 31). Głową rodziny była Józefa Kawałko - w Zestawieniu pod nazwiskiem panieńskim - Józefa Kuczmowska (pozycja 95) oraz Józefa Rudnik - w Zestawieniu pod nazwiskiem panieńskim Józefa Gołąb (pozycja 25). Wielkość gospodarstwa przyznanego rodzinie Adeli Dumańskiej należy szukać w Zestawieniu pod nazwiskiem Józef Gawryluk 
przez Polską Partię Robotniczą zasadami przebudowy stroju agrarnego, wielkość gospodarstw osadniczych, według okólnika Ministerstwa Ziem Odzyskanych z 15 lipca 1946 r., ustalono na 7-15 ha ${ }^{112}$. Zgodnie z zarządzeniem Państwowego Urzędu Repatriacyjnego warunkiem przesiedlenia chętnych osób z centralnych obszarów Polski było przekazanie ich gospodarstwa na rzecz Skarbu Państwa ${ }^{113}$. Na ziemiach zachodnich urzędnik PUR miał każdego takiego przesiedleńca wprowadzić do przydzielonego gospodarstwa, a następnie sporządzić opis przydzielonego mienia ${ }^{114}$. Adela Dumańska mówiła: „ci z centralnej Polski nie mieli prawa do domów tu, a my byliśmy wysiedleńcy, nie mieliśmy nic ze sobą i te tereny, domy tutaj nam się należały”. Podobnie zapamiętała D. Domańska: „...bo my mamy papiery ewakuacyjne, a kto nie miał, np. ci z centralnej Polski, to oni musieli spłacać te domy”. Józefa Rudnik dodała: „nam się tu wszystko należało, bo my repatrianci, ale my nie wiedzieli, dla nas UNRRA paczki posyłała a gmina brała, wójt, sołtys, sołtys to był nasz, sekretarz i wszystko oni zabierali. A to było dla nas, my mieliśmy akt nadania, kartę majątkową. To, co tam mieliśmy, to tutaj nam oddadzą". O władzach mówiła: „cały urząd gminy to byli ludzie z centralnej Polski, nikt się nie pchał z nas, był zajęty swoim. [...]”. D. Sula stwierdziła, że możliwość zmiany miejsca zamieszkania (szczególnie z województw zniszczonych działaniami wojennymi i przeludnionych) oznaczała pojawienie się nowych perspektyw: lepsze warunki materialne, awans społeczny ${ }^{115}$, zdobycie majątku. Wśród przesiedlanych byli też tzw. pionierzy, którzy „przybyli kierowani potrzebą przywrócenia tych ziem Polsce” ${ }^{{ }_{116}}$. Być może $\mathrm{z}$ tego powodu przesiedleńcy z ziem dawnych chętnie angażowali się

(pozycja 65). Prawdopodobnie wystąpił błąd w zapisie i chodzi o Józefa Gabryluka, ojca Adeli Dumańskiej, a przemawiałby za tym fakt, że zgadza się numer domu przy tym nazwisku z numerem domu, pod którym mieszkała Adela. APWr, PUR, sygn. 59o, k. 489-49o. Zestawienie $n r 1$ osiedlonych rodzin na dzień 1 sierpnia 1946 r., Gromada Domajowice, gmina Domajowice, powiat Otawa, [w:] Powiatowy Oddziat PUR. Imienne spisy osadników osiedlonych w powiecie Oława, Oleśnica. Spis osiedlonych od $n r$ 1-677, $1946 \mathrm{r}$.

112 W. Borodziej, S. Ciesielski, J. Kochanowski, op. cit., s. 46.

113 D. Sula, op. cit., s. 94.

114 Ibidem.

115 Ibidem, s. 100.

116 M. Hejger, op. cit., s. 37. 
w tworzenie miejscowej administracji. Niemiecki badacz Philipp Ther wyjaśnia to tak, że osiedleńcy z Kresów „z powodu wypędzenia oraz wcześniejszych doświadczeń z Sowietami najczęściej byli nastawieni antykomunistycznie. Przynajmniej w pierwszych latach po wojnie ludzie z Polski centralnej mieli pierwszeństwo przy obsadzaniu stanowisk w państwie i partii komunistycznej, a wypędzeni ze Wschodu byli krytykowani jako zbyt nacjonalistyczni i wiecznie niezadowoleni" ${ }^{117}$.

Początkowo wśród osiedleńców z Uszni dominowało poczucie tymczasowości. Równocześnie respondentki podkreślały poczucie bezpieczeństwa i lepszych warunków bytowych ${ }^{118}$. „Podczas wojny była bieda, coś strasznego - wspomina Adela Dumańska - była bieda jak mieszkaliśmy na Wschodzie. Tu był dobrobyt, wszędzie pola zasiane, domy murowane, człowiek się poczuł”. Domicela Domańska pamięta, że „Mój tato chciał wracać do Uszni, ale to nie było sensu, bandery byli, mordowali, tu całą noc spokojnie spali”. Józefa Rudnik wspominała: „Moja mama pół roku bagaży nie rozpakowywała: »My pojedziemy na Usznię« - mówiła. A my jak tu mogliśmy spokojnie spać, nie bali się że banderowcy przyjdą i nas pozarzynają - a to było coś strasznego"! Rodzina Domiceli Rypałowskiej również początkowo myślała o rychłym powrocie, ale „potem już był sołtys, zaczynali zboże dawać, siali, orali, potem zaczynali dzielić pole, każdy miał swoje" i tym sposobem zadomowili się na nowej ziemi.

Ze wspomnień wynika, że najpoważniejszym problemem trapiącym mieszkańców i nowych osadników była epidemia tyfusu oraz insektów ${ }^{119}$. „Tutaj bardzo Niemcy umierali na tyfus, jak my tu przyjechali, Polacy nie umierali (choć też chorowali), bo my tu bimbru narobili" - mówi Józefa Rudnik. Domicela Rypałowska pamięta jak: „potem rzucił się tyfus, ludzie umierali, nasza Niemka 10-letniego chłopczyka zostawiła”. Z kolei Adela Dumańska mówiła, że niemal codziennie był pogrzeb. Ponadto przyznała, że: „w domach w Domaniowie było pełno karaluchów, nie było ich czym wytępić. Dom był zadbany, ale ich pełno”.

\footnotetext{
117 P. Ther, op. cit., s. 227-228.

118 Por. D. Sula, op. cit., s. 67.

119 Por. M. Hejger, op. cit., s. 8o-81.
} 
Bardzo często zdarzało się, że przybysze z Kresów osiedlali się w domach, które dzielili z Niemcami jeszcze przez około rok. Okazuje się, że mimo koszmarnych wspomnień z czasów wojny, uprzedzenia i chęć odwetu nie wzięły góry. Współżycie z Niemcami w tym okresie należy do dobrych wspomnień. Po trosze dzielili wspólny los przesiedleńców, co spotykało się z obustronnym zrozumieniem i współczuciem. „My rok jeszcze z Niemcami mieszkali - wspomina Józefa Rudnik - ja nie mieszkałam tu, gdzie obecnie, tylko tam gdzie brat, moja siostra też mieszkała. My tam na początku wszyscy mieszkali. Dwa pokoje nam Niemka dała, siostra miała dwójkę dzieci. [...]W pierwszym domu było nas za dużo, więc przenieśliśmy się do innego [tam gdzie obecnie mieszka - przyp. N.J.]. Tam była Niemka i Niemiec, mieli dwóch chłopaków i tu moja siostra przyszła”. O stosunkach z miejscowymi Niemcami mówiła: „Nas tutaj na rogu nieraz stało 10-15 osób, śpiewaliśmy do 24.[...] A my tu z tymi dziewczętami chodzili, Niemiec grał na bębnie... my graliśmy, tańczyliśmy na podwórku, tak było i właśnie z tymi dziewczynami niemieckimi my chodzili, nawet nie wiem jak się dogadywaliśmy, ale jakoś tak. Te Niemcy stąd to oni trochę inaczej mówili jak ci twardzi Niemcy, myśmy jakoś mieli wspólny język. Chodziliśmy z nimi na zabawy, tańczyli, fajnie było. Nikomu krzywdyśmy nie zrobili. Tutaj przez parę lat przyjeżdżali ci Niemcy, nie ta pani, tylko jej 3 siostry. Zapraszałam ich na kawę, placek. Od tamtej pory przyjeżdżali każdego roku, brali sobie autokar, przyjechali pod kościół i tam mieli kuchnię swoją, ksiądz dawał msze św. Tak cieszyli się, jak ktoś ich ugościł. Dwa obrazy świętej rodziny po Niemcach zostały. Oni się bardzo cieszą jak tu porządek”.

Józefę Kawałko do Domaniowa sprowadził w 1946 r. starszy brat Józef, który wrócił z wojny i odnalazł rodzeństwo. Chcieli zamieszkać w Thomaskirch, ponieważ tam był kościół, urząd gminy i szkoła, a młodszy brat Józefy, Bronisław, był w wieku szkolnym. „Ale wszystko dobre było już zajęte - wspomina Józefa - jednak on znalazł ten dom, w którym teraz mieszkam. Przez pewien czas mieszkaliśmy z Niemcami. Oni poszli na górę: Niemka, jej mały synek, stary ojciec i matka stara, chora na tyfus. Mąż Niemki młodej był na wojnie. Brat był cięty na nich, bo widział, gdy oswobadzali Oświęcim, jak tam ludzie biedni byli. On Niemcom to wypominał, ale myśmy w zgodzie z nimi żyli. Oni pomagali mnie młócić. Potem wyjechali do Niemiec Zachodnich. Młoda Niemka mówiła, że jej mąż na wojnie i ona tam jedzie. Dałam jej trochę marek, bo brat przywiózł z frontu, to potem 
listy pisała, że dzięki tym pieniądzom uratowałam jej życie. Potem przyjeżdżała ona do nas i brat jej męża. Przyjęłam ich, ugościłam, nawet filiżanki dostałam od nich w prezencie, byli bogaci, mam je do dziś. Wszędzie zaglądali, nawet na strych, chwalili, że ładnie i czysto".

O dobrych stosunkach z Niemcami i ich potomkami wspominała też Domicela Domańska: „też jeździłam do Niemiec odwiedzać tych, co tu mieszkali. Raz to nawet na uroczystość komunii świętej do nas przyjechali. Pamiętam też, że Niemka bardzo chciała, żebym zrobiła jej poduszkę z pierza. Wzięła ją na pamiątkę do Niemiec".

Podobnie wypowiadała się Adela Dumańska: „nasze Niemcy wyjeżdżali szybciej, bo wiedzieli, że pierwszy transport jedzie do Niemiec Zachodnich. Tato prosił Niemca - »ja cię nie wypędzam «, dobrze my żyli z tymi Niemcami, a on mówił, że już jedzie, bo chce do Niemiec Zachodnich. To było na wiosnę 46 r. [...] Z Niemcami mieszkało się dobrze, to byli dobrzy ludzie. Mama zachorowała na tyfus, babci żylaki - rany się porobiły. Niemkom Hitler pozabierał mężów i synów, biedowali, bo nie każdy umiał sobie dać radę. Mieszkał z nami taki mały Josef, który często siadał na schodach, wiodących do nas, na piętro, a co moja mama ugotowała, to on dostawał i jadł. Niemka krzyczała na niego, ale nam też coś dawała. Dzieliliśmy się, choć była bieda".

\section{Wysiedlenie ludności niemieckiej}

W czasie konferencji w Poczdamie podjęta została decyzja o wysiedleniu z Polski ludności niemieckiej. Część Niemców opuściła tereny przyznane Polsce do jesieni 1945 r. w wyniku ewakuacji, ucieczek, dobrowolnych wyjazdów i wysiedleń wojskowych ${ }^{120}$. Nadal jednak większość niemieckich obywateli, dotychczasowych gospodarzy, przebywała w swoich domach, licząc na zmianę sytuacji. Tymczasem na tereny Dolnego Śląska napływali przesiedleńcy z Kresów Wschodnich. Pojawiły się trudności aprowizacyjne, przeludnienia, pogarszał się stan bezpieczeństwa ${ }^{121}$. Masowe wysiedlenia rozpoczęto po podpisaniu umów z władzami stref okupacyjnych Niemiec. W połowie lutego 1946 r. podpisano układ z Brytyjczykami, w którym ustalono, że w pierwszej kolejności do brytyjskiej strefy okupacyjnej będą

120 Ibidem, s. 186.

121 G. Hryciuk, M. Ruchniewicz, B. Szaynok, A. Żbikowski, op. cit., s. 186; M. Ruchniewicz, Lata 1945-1948..., s. 637. 
wysyłani Niemcy z Pomorza Zachodniego, Dolnego Śląska i dawnego Wolnego Miasta Gdańska ${ }^{122} .19$ lutego 1946 r. wyruszyły pierwsze transporty z Dolnego Śląska. Od lipca pociągi z wysiedlanymi trafiały do radzieckiej strefy ${ }^{123}$. Od lutego 1946 r. do końca tego roku wyjechało z Dolnego Śląska ok. 1 mln 35 tys. Niemców, z czego zdecydowana większość trafiła do brytyjskiej strefy okupacyjnej (720 tys. $)^{124}$.

Na terenie gminy Domajewice (powiat oławski) było 188o Niemców. Wysiedlenie ludności niemieckiej z terenu powiatu oławskiego rozpoczęło się 13 czerwca 1946 r. Punkt zbiorczy znajdował się w Laskowicach, pierwszy transport wyprawiono 14 czerwca, a ostatni 20 czerwca. Łącznie wysłano 7 transportów zawierających 12491 osób (w tym 916 z miasta Oława i 11575 z powiatu oławskiego) ${ }^{125}$. W dniu 8 maja 1947 r. odszedł jeszcze jeden transport niemiecki z punktu zbiorczego w Laskowicach składający się z 1500 osób ${ }^{126}$. Jak wynika z zebranych relacji bogatsi Niemcy wyjeżdżali do brytyjskiej strefy, a biedniejsi do radzieckiej ${ }^{127}$. „Jak Niemcy wyjeżdżali to najpierw ci bogatsi do RFN, ci biedniejsi do NRD" - opowiada Józefa Rudnik. Domicela Domańska wspominała: „[...] a później Niemcy wyjechali, co mieli zabrali, jechali do RFN, a dziady do NRD”. Ponadto zabrali ze sobą co cenniejsze rzeczy: „Niemcy na górze mieszkali, zabierali ze sobą rzeczy wartościowe, ale to ci bogatsi Niemcy, np. ten spod 1. Kresse był bogatym gospodarzem" - mówi Adela Dumańska. Pozostały rzeczy, które nie były przydatne z punktu widzenia rolnika. „Po Niemcach została sieczkarnia, stare rzeczy, barachło - ani konia, ani krów. Na dole było piękne pianino, ale sołtys zabrał" - relacjonuje Domicela Domańska.

Warto jeszcze dodać, iż na początku osadnictwa Kresowian w Domajowicach „był tu niemiecki ks. Pastuszek ${ }^{128}$, z Niemcami wyjechał” - relacjonuje

122 G. Hryciuk, M. Ruchniewicz, B. Szaynok, A. Żbikowski, op. cit., s. 189.

123 Ibidem.

124 M. Ruchniewicz, Lata 1945-1948..., s. 645.

125 APWr., PUR, sygn. 214, k. 145 oraz APWr., PUR, sygn. 780, k. 650.

126 APWr., PUR, sygn. 780, k. 543-603.

127 W dostępnej literaturze nie znalazłam potwierdzenia, że istniała taka prawidłowość. Natomiast zgadza się fakt wyjazdów Niemców najpierw do strefy brytyjskiej, potem radzieckiej, o czym pisałam wyżej.

128 Karl Pastuszyk, proboszcz w Thomaskirch (obecna nazwa Domaniów), okręg oławski, liczba wiernych 1304. Handbuch des Erzbistums Breslau für das Jahr 1942, Breslau 1942, s. 28. Był proboszczem w latach 1933-1945. Domaniów. Przeszłość..., s. 19. 
Adela Dumańska. „Były też niemieckie siostry zakonne, leczyły na tyfus Niemców i Polaków”. J. Rudnik pamięta, że: „Tu był ksiądz niemiecki, ale myśmy uzgodnili, że jak było nabożeństwo np. majówka dla Niemców o 18.30, to u nas o 19.0o. Ks. niemiecki odprawiał i chował, ale nie spowiadał".

\section{Kresowe dziedzictwo}

Mieszkańcy Uszni przywieźli do Thomaskirch swoją kulturę, zwyczaje i wiarę. Kresowiacy kontynuowali edukację, uczestniczyli w różnych kursach. Byli bardzo aktywną i zaangażowaną społecznością. „Jak myśmy tu przyjechali, to przywieźliśmy tutaj naszą kulturę ze Wschodu - wspomina Józefa Rudnik. My przyjechaliśmy w sierpniu, a już na Boże Narodzenie były jasełka. Mężczyźni zrobili scenę, byliśmy bardzo aktywni, a dlaczego? My to bardzo przeżyliśmy, jak my tu przyjechaliśmy, że nas tutaj nikt nie zaczepiał, że nie musieliśmy się bać tych banderowców, to była radość między nami. [...] Mieliśmy koło gospodyń złożone z piętnastu osób, powstało w latach 50. Był kurs szycia, dużo mnie to dało, bo ja sama szyła, ale nie bardzo umiała. Poszłam na kurs i wiedziałam, że pod pachą trzeba $9 \mathrm{~cm}$ wykroić. Mieliśmy kurs pieczenia i gotowania. Graliśmy Wesele na Uszni, które wystawialiśmy we Wrocławiu. Zawieźliśmy tam konie, wóz, wszystko. Był korowaj [rodzaj kołacza, obrzędowe pieczywo przygotowywane na wesele - przyp. N.J.] krojony. Gotowaliśmy zaprażkę (taki sos) w glinianym naczyniu i to wszystko do Wrocławia zawieźli. Z Rypałowską to my zrobiły 500 pierogów i wzięliśmy, wszystko poszło. Śpiewałam wiele lat w chórze”. W domaniowskim zespole chórzystów śpiewała też Domicela Rypałowska.

Domicela Rypałowska wraz z mężem zaangażowała się w aktorstwo i lokalne inicjatywy kulturalne. „Mąż wrócił z pracy przymusowej z Niemiec po żniwach, koło września 1945 r. - wspomina. - Graliśmy różne przedstawienia, prowadziliśmy chór. Przed Bożym Narodzeniem jasełka graliśmy. Zrobiliśmy scenę w obecnym Gminnym Ośrodku Kultury w Domaniowie w 1946 r., nawet w Kończycach wystawialiśmy tę sztukę. Oprócz tego graliśmy Consilium facultatis, Jeden z nas musi się ożenić, Moralność pani Dulskiej, Pani Dulska przed sadem. Mąż śpiewał w chórze, ja w chórze śpiewałam 60 lat i przeżyłam 67 lat małżeństwa".

Mąż Domiceli Rypałowskiej, Tadeusz, uczył w miejscowej szkole. „Mój mąż był nauczycielem, uczył analfabetów" - mówi Domicela. Józefa Rudnik dodała, że uczył on matematyki. Pamięta, że dużo umiała, ponieważ była zdolna w rachunkach. Oprócz tego w tutejszej szkole matematyki, fizyki i przyrody nauczał ks. Bronisław Goldewicz, również pochodzący z Usz- 
ni. Według Domiceli Domańskiej uczył też języka polskiego i religii. Natomiast Adela Dumańska wspomniała innych nauczycieli: „Tato pojechał do Wrocławia, przywiózł dwie nauczycielki, jedna nazywała się Millerowa. Za parę lat był też nauczyciel Dąbrowski".

\section{Razem raźniej - podsumowanie}

Domaniów jest przykładem zasiedlania, jakie często miało miejsce w tym czasie. Cechą charakterystyczną osadnictwa Polaków - Kresowian, szczególnie z Galicji Wschodniej, była jego zwartość ${ }^{129}$. Ludzie przenoszący się z jednej wsi czy okolicy chcieli mieszkać razem w nowym miejscu, obok dawnych sąsiadów, często z własnym proboszczem. Podobną prawidłowość zauważyła H. Murawska u przesiedleńców z Wileńszczyzny. Ludzie przybywali stamtąd całymi wielopokoleniowymi rodzinami, niekiedy całą społecznością i swoim proboszczem, zatem i na nowych ziemiach osiedlili się całą wsią czy społecznościąa ${ }^{130}$. W trudnych czasach ta wspólnota dawała im poczucie bezpieczeństwa, oparcie, namiastkę swojskości, kontynuację starych więzi i tradycji ${ }^{131}$. Jak podkreślały moje rozmówczynie, bardzo ważną postacią dla byłych mieszkańców Uszni był ksiądz Eugeniusz Nowak. W trudnych czasach, jakimi było przesiedlenie, otaczał ich opieką, którą oni określają jako serdeczną i ojcowską. Józefa Rudnik wyjaśniła, jak poznali kapłana: „a ksiądz Nowak przypadkowo się dostał do nas [naszego transportu], dlatego że on był misjonarzem i jechał z misją. On był [na parafii] w Złoczowie". Ks. Nowak zżył się z uszniakami, a potem domaniowianami, których proboszczem był przez dwa lata. Józefa Rudnik dodaje: „ks. Nowak uczył w Oławie, a co 2 tygodnie mszę odprawiał w Domaniowie". Uważali go za mądrego człowieka i liczyli się z jego zdaniem, otaczając wielkim szacunkiem. Miał też duże poczucie humoru. „Dzięki Bogu i ks. Nowakowi, że my znaleźliśmy się w Domaniowie przyznaje Adela Dumańska - on się naprawdę nami opiekował. Jechał wagonami jak każdy. Przyjechał do Laskowic, my w takich budach mieszkali, wziął parę mężczyzn na koniach i szukali miejscowości, gdzie byłby kościół, szkoła, wybrukowane ulice i jedziemy tam. On nas konwojował".

129 M. Ruchniewicz, Lata 1945-1948..., s. 648.

130 H. Murawska, Przesiedleńcy z Kresów Północno-Wschodnich II Rzeczypospolitej w Olsztyńskiem, Olsztyn 200o, s. 158.

131 M. Ruchniewicz, Lata 1945-1948..., s. 648; H. Murawska, op. cit., s. 158. 
164 Z okazji 50-lecia kapłaństwa parafianie z Domaniowa wystarali się dla niego o Złoty Krzyż Zasługi. Wraz z chórem „Jubilat” odwiedzili go też w Krakowie, gdzie wspominali dawne, wspólne czasy.

„[...] Jedni drugim pomagali, co roku było lepiej, tylko potem komuna nas gnębiła" - podsumowuje Adela Dumańska. Przesiedleńcy z Uszni ostatecznie zadomowili się w swojej nowej „małej ojczyźnie” - Domaniowie, w której do dziś pielęgnują pamięć o przodkach oraz kulturę i tradycje przywiezione ze Wschodu. Pamięć ta jest wciąż istotna. Było to widoczne nie tylko w 1985 r., kiedy to wzniesiono pomnik „Orlicy z orlętami”, upamiętniający przybycie pierwszych osadników ze Wschodu w 1945 r. Do dziś organizowane są wycieczki do Uszni i okolic, w których biorą liczny udział nie tylko Kresowianie, ale ich dzieci i wnukowie. Również działający wciąż chór, mający korzenie w Uszni, to swoisty łącznik przeszłości i teraźniejszości, ślad pamięci i kontynuacji kultury. Powodzeniem cieszą się również spotkania (np. opłatkowe, w okresie karnawału) byłych Kresowian, na których z chęcią pojawiają się dzieci byłych mieszkańców Uszni. 
Domaniów is a small town in the Oławski region in Lower Silesia. After the Second World War a large group of former residents of Usznia, a small village in the Eastern Borderlands of the Second Polish Republic, settled down in Domaniów. The author presents the accounts of five people who participated in the relocation process. The memories also include the time of their childhood and teenage years. The interviewees described how they remembered their family village, the most significant events from the time of war (German and Russian occupation), the preparation for relocation and the journey to the West - into the unknown. The accounts also show why Domaniów, which was known as Domajewice at that time, was selected as the settlement place, how it looked and what were the relationships with the Germans who still lived there. The author also describes the culture and traditions brought from the East and how they are continued to this day. The memories were set in a historical context based on the subject literature and archival materials.
Natalia

Jakubowska

Between Usznia and Domaniów. Migrants from the Eastern Borderlands settling in the Western Lands 